Review

\title{
A Systematic Review on Technologies for Data-Driven Production Logistics: Their Role from a Holistic and Value Creation Perspective
}

\author{
Masoud Zafarzadeh ${ }^{1, *(D)}$, Magnus Wiktorsson ${ }^{1(D)}$ and Jannicke Baalsrud Hauge ${ }^{1,2}$ \\ 1 Department of Sustainable Production Development, KTH Royal Institute of Technology, \\ 11428 Stockholm, Sweden; magwik@kth.se \\ 2 BIBA Institute, 28359 Bremen, Germany; jmbh@kth.se \\ * Correspondence: masoudz@kth.se; Tel.: +46-8-790-94-93
}

Citation: Zafarzadeh, M.;

Wiktorsson, M.; Baalsrud Hauge, J. A Systematic Review on Technologies for Data-Driven Production Logistics: Their Role from a Holistic and Value Creation Perspective. Logistics 2021, 5 , 24. https://doi.org/10.3390/ logistics5020024

Academic Editor: Benjamin Nitsche

Received: 25 February 2021

Accepted: 23 March 2021

Published: 23 April 2021

Publisher's Note: MDPI stays neutral with regard to jurisdictional claims in published maps and institutional affiliations.

Copyright: (c) 2021 by the authors. Licensee MDPI, Basel, Switzerland. This article is an open access article distributed under the terms and conditions of the Creative Commons Attribution (CC BY) license (https:// creativecommons.org/licenses/by/ $4.0 /)$.

\begin{abstract}
A data-driven approach in production logistics is adopted as a response to challenges such as low visibility and system rigidity. One important step for such a transition is to identify the enabling technologies from a value-creating perspective. The existing corpus of literature has discussed the benefits and applications of smart technologies in overall manufacturing or logistics. However, there is limited discussion specifically on a production logistics level, from a systematic perspective. This paper addresses two issues in this respect by conducting a systematic literature review and analyzing 142 articles. First, it covers the gap in literature concerning mapping the application of these smart technologies to specific production logistic activities. Ten groups of technologies were identified and production logistics activities divided into three major categories. A quantitative share assessment of the technologies in production logistics activities was carried out. Second, the ultimate goal of implementing these technologies is to create business value. This is addressed in this research by presenting the "production logistics data lifecycle" and the importance of having a balanced holistic perspective in technology development. The result of this paper is beneficial to build a ground to transit towards a data-driven state by knowing the applications and use cases described in the literature for the identified technologies.
\end{abstract}

Keywords: data-driven; smart; process automation; production logistics; technology; transition; autonomous systems

\section{Introduction}

Recent developments in information and communication technologies (ICT) have the potential to create business value by supporting the transition towards data-driven manufacturing and autonomous supply chains [1,2]. These technologies enable seamless data flow and link information to moving goods and material. Implementation of these technologies is not only a prerequisite for data-driven manufacturing and autonomous supply chains [3,4], but also increases visibility in the internal logistics operations.

Within data-driven manufacturing, data is the backbone of the system, which embodies intelligence into manufacturing systems. Tao et al. [5] have conceptualized data-driven smart manufacturing and identified several characteristics. Data-driven manufacturing systems are self-regulated through exploiting real-time monitoring of manufacturing processes. Through exploiting multisource data from manufacturing processes, it will be possible to have rigorous control over the production process. By applying resource-related data, tasks and work instructions data, it will be possible to have smart planning and scheduling across the organization. Customer data such as demands, preferences, limitations and behaviors will be considered for overall system efficiency. Through exploiting historical and real-time data, it will be possible to perform quality control and preventative 
maintenance proactively [6]. These characteristics open up a new horizon for production logistics (PL), which is indispensable for any manufacturing system.

Even if it be claimed that data-driven smart manufacturing characteristics are valid for production logistics [5], current practices within production logistics is still perceived as a field tied up with non-value-adding activities and lacking high level of responsiveness. To understand the importance of streamlining the PL processes through digitalization, following statement is interesting to consider: "A typical manufacturing company dedicates $25 \%$ of its employees, $55 \%$ of its factory space, and $87 \%$ of its production time to material handling" (Horňáková et al. [7]; adopted from Davich [8]). To facilitate the transition towards data-driven production logistics, it is important to have a systematic perspective regarding the possibilities created by technologies. Several studies reviewed these enabling technologies on a high level in connection with concepts such as smart manufacturing [9], smart logistics [10] and Industry 4.0 [11]. On the other hand, there are studies that looked in to this domain in more details by investigating the application of data-driven technologies in one specific area such as tracing [12], route planning [13] or warehousing [14]. However, the literature has a gap in addressing the application of data-driven enabling technologies in production logistics from a systematic point of view, covering all the activities in a PL system. Thus, we are dealing with studies either conceptualizing data-driven related topics by discussing the possibilities that the technologies can create on enterprise level or reporting benefits on detailed level.

In addition to this existing gap, Klingenberg et al. [11] argue that the absence of a framework in the existing literature reviews with respect to data as the main building block of the data-driven technologies leads to a conceptual panacea. As a consequence of this issue, it is not clear how these technologies in cooperation with each other can contribute to create value for the production logistics systems.

This study intends to cover the described gap by a systematic literature review of reported applications of enabling technologies in production logistics activities, in order to clarify how technologies, in cooperation with each other, can create value for PL systems.

\subsection{Related Works and Research Gaps}

Perceived benefits is one of the major determinants in employing smart data-driven technologies and methods [15]. Thus, it is necessary to clarify what benefits can be gained through technologies implementation for companies. As mentioned, earlier studies either review the data-driven enabling technologies on the enterprise level, such as smart manufacturing, smart logistics and Industry 4.0, or discuss the subject on a detailed level focusing one specific application. For example, enabling technologies for Industry 4.0 with focus on state-of-the-art and future trends by Alcacer and Machado [16], presenting and discussing key technologies and their characteristics, and the concept of a smart factory. They describe the enabling technologies, but little attention has been paid to the use cases and especially internal logistics of manufacturing firms. Furthermore, innovative technologies adopted in logistics management is reviewed by Lagorio et al. [17], and implementation of Industry 4.0 related technologies within intralogistics is discussed by Saucedo and Jania [18]. In another study, 11 groups of smart manufacturing enabling technologies were identified and their association with smart manufacturing characteristics investigated by Mittal et al. [19], discussing the application of these technologies on a high level. Oztemel and Gursev [20] is another example reviewing the enabling technologies and some initiatives and projects related to Industry 4.0. One study that has discussed application examples of smart manufacturing, is done by Thoben et al. [21], who have mentioned internal logistics in a form of cyberphysical logistics systems. Some other studies have covered technologies applications and use cases targeting production logistics [22-24], but these research lack a systematic perspective to cover all the related PL activities. From a supply chain perspective, Chavez et al. [25] introduced a conceptual framework for data-driven supply chains. Still, the framework does not detail the connection to the enabling technologies and some specific areas of internal logistics such as material handling. 
In conclusion, even though the mentioned reviews have analyzed applications related to internal logistics, the overall picture is fragmented and it is not possible to draw a conclusion on how these technologies can actually be useful for production logistics, from a system perspective. Either the existing reviews aim to determine the benefits of implementing enabling technologies on the enterprise level, or they study the application of a selected set of enabling technologies on a detailed level. For example, using RFID for items tracing [12], cloud robotics for route planning [13] or Internet-of-Thing for warehousing [14].

\subsection{Research Purpose, Motivation and Article Structure}

The purpose of this article is to review the data-driven enabling technologies and their relation with production logistics activities, from a comprehensive and system perspective. Building upon the identified gap presented in Section 1.1 above, there are three major reasons to perform a systematic literature review in this respect.

First, as technological advancements have created more opportunities to collect big amount of data from various data sources, the term data-driven appears in literature more often. Data-driven is widely discussed in relation to decision-making science. However, from the production logistics perspective and in conjunction with topics such as Industry 4.0 and smart manufacturing, this concept is still elusive with different interpretations, needing clarity. In a study by Rossit et al. [26], it is discussed as a scheduling approach in smart manufacturing and cyber-physical systems (CPS). Even though they have referred to frameworks developed for data-driven decision-making, the result of the work is limited to scheduling and other activities are not addresses. In another example, Woo et al. [27] introduced big data analytics platform in manufacturing. In their platform, data-driven models used a predictive planning tool to support decision-making. In some other studies, the term data-driven is used to describe the aim of the research but there is little effort to clarify the data-driven concept in the text, e.g., [12,28,29].

Second, as described in Section 1.1, PL can be perceived as a subsystem for either manufacturing or supply chain. The consequence of this duality is that it is not clear when to apply what technology, and for which production logistics activity. There are studies that have reviewed the data-driven and smart-manufacturing enabling technologies $[11,16,19,27,28]$. However, to the knowledge of the authors, there is no literature review dedicated to production logistics. In this research, production logistics refers to those activities that happen within production systems. In other words, the internal logistics activities that aim to support manufacturing or production in terms of planning, control and configuration of logistics flow, is considered as production logistics [30]. All the materials, tools and information flow that are necessary for a balanced and efficient production process, are components of production logistics [31].

Third, as ICT technologies are constantly evolving, there is a need to have an updated view on technologies that enable data-driven PL. In this research, data-driven production logistics refers to a closed loop PL system where all the activities are triggered by data and the outcome of activities are presented with data for further use. In this respect, data is collected from various sources by means of enabling technologies. Data analysis has a wide scope in order to have an accurate representation of physical objects and processes. Data need to be internalized through data integration, discovering meaningful information through extracting data features. The data time line has importance for the PL data-driven system, as some activities such as fleet control require real-time data in order to create value for the system.

The technologies discussed in the literature can be considered to be on three different levels [11]. The first is on the device or component level such as sensors or RFID (radio frequency identification), which usually are physical entities. The second is on the method level such as Wi-Fi. Connectivity protocols and software system development approaches such as SoA (service oriented architecture) are perceived as methods. The third is on the system level such as IoT (Internet-of-Things) and CPS (cyber-physical systems), which 
may consist of several devices and methods. As a result, in this article technology refers to devices, methods and systems, which are the result of scientific knowledge being used for practical purposes, in line with Collins dictionary [32].

In order to meet the purpose of this paper and cover the discussed gaps, it is first required to identify the enabling technologies and their application in PL. Secondly, it is necessary to understand how can the identified technologies create value from a system perspective. Two key research questions were posed in guiding the review:

1. What are the data-driven enabling technologies and their use cases in production logistics activities, as described in the literature?

2. How does the data-driven enabling technologies contribute to value creation in production logistics from a system perspective?

In the following section, the review methodology is outlined. In the result section, findings on the identified technologies key activities (RQ1) and the value creation discussion (RQ2) are presented. Based upon these findings, the discussion elaborates on the role of data life cycle in value creation for/within production logistics. In addition, the interconnection of the identified technologies was discussed. Finally, the article culminates with conclusions and future research possibilities.

\section{Methodology}

The method selected for reviewing the technologies enabling the data-driven smart production logistic was a systematic literature review (SLR). SLR was chosen as it helps to bring together relevant studies regardless of their location or even disciplinary background. Furthermore, an advantage of SLRs is that by keeping the research process transparent and unbiased, readers can have a clear conclusion and provide new opportunities for other researchers to have new experiments by knowing the exact details of the study performed according to SLR. In addition, properly managed, an SLR can shed light on a specific aspect of the reviewed studies [33]. In this case, this SLR highlights production logistics as one key manufacturing subsystem, which requires further studies. To the best of our knowledge, there is no literature review that has mapped the technologies and their relation to production logistics activities in the context of Industry 4.0 and smart manufacturing. This SLR is carried out in-line with the approach suggested by Tranfield, Denyer and Smart [34], using a three-stage process to perform a systematic literature review: (1) planning the review, (2) conducting the review and (3) reporting and dissemination.

\subsection{Planning the Review}

This first stage concerns planning the review of literature covering technologies enabling data-driven PL activities. To perform the review, several databases were examined and Scopus was chosen since it is the largest abstract and citation database of peer-reviewed literature. Compared to other examined databases, this database has rich material regarding production logistics, smart manufacturing, Industry 4.0 and data-driven enabling technologies. Scopus also integrates other databases such as the Web of Science, which makes it a reliable source for this study.

Initial Scoping

In order to define the initial scope, the authors defined three categories of search keywords/terms. Category 1 concerns keywords related to emerging concepts such as data-driven manufacturing/logistics, smart/intelligent manufacturing, smart/intelligent logistics, smart/digital factory, Industry 4.0, cyber-physical systems (CPS), digital twin, and Internet-of-Things (IoT). As the primary goal of this paper was to emphasize the role of data in PL systems, data-driven was chosen for the first category. Amongst the mentioned terms, Industry 4.0 is an elusive concept, vaguely defined and including a multitude of concepts [35], and already broadly discussed in the literature, hence excluded. The other terms such as CPS, IoT and digital twin have been mentioned in some of the literature as enabling technologies. Choosing any of these more specific terms could limit the search 
scope. Terms such as smart/digital factory are less common compared to smart/intelligent manufacturing. To choose between smart and intelligent, the number of hits in Google Scholar was compared. Consequently, beside data-driven, smart was chosen as the second keyword for the first category. Category 2 frames the context of the study. Authors dealt with several options such as manufacturing logistics, production logistics and internal logistics. As internal logistics applies to any possible sort of operation such as a healthcare system, hence is this term not appropriate for this research. As both the "manufacturing" and "logistics" terms have relevant material, it was decided to keep both of the terms for the second category. Category 3 defines the ultimate search items, which is the technologies. To make sure other related work would be captured, "solution" was also added to this category as the last keyword.

\subsection{Conducting the Review}

As a consequence of the initial scoping, the search query was defined as follows: (("datadriven" OR smart) AND (manufacturing OR logistic*) AND (technolog* OR solution*)).

A wildcard was used to maximize the search outcome. The results were limited from different angles: Time was limited from 2016-March 2020, language was limited to "English". In order to ensure the quality of the material, only those articles that are published in journals picked for further review and the type of sources was limited to "journals". Subject areas were limited to the following:

- Engineering;

- Computer Science;

- Business, Management and Accounting;

- Decision Sciences;

- Mathematics;

- Social Sciences;

- Economics, Econometrics and Finance;

- Environmental Science.

In addition, in order to make the search query even more precise, several keywords that were not relevant to this research, such as machining, cryptography, semiconductors, additive manufacturing, 3D printing and reference modeling were excluded from the search. This search query resulted in 717 hits. Figure 1 illustrates the number of articles per year from 2016 to mid-2020. It is clear that data-driven smart manufacturing and data-driven smart logistics are increasingly receiving attention by researchers.

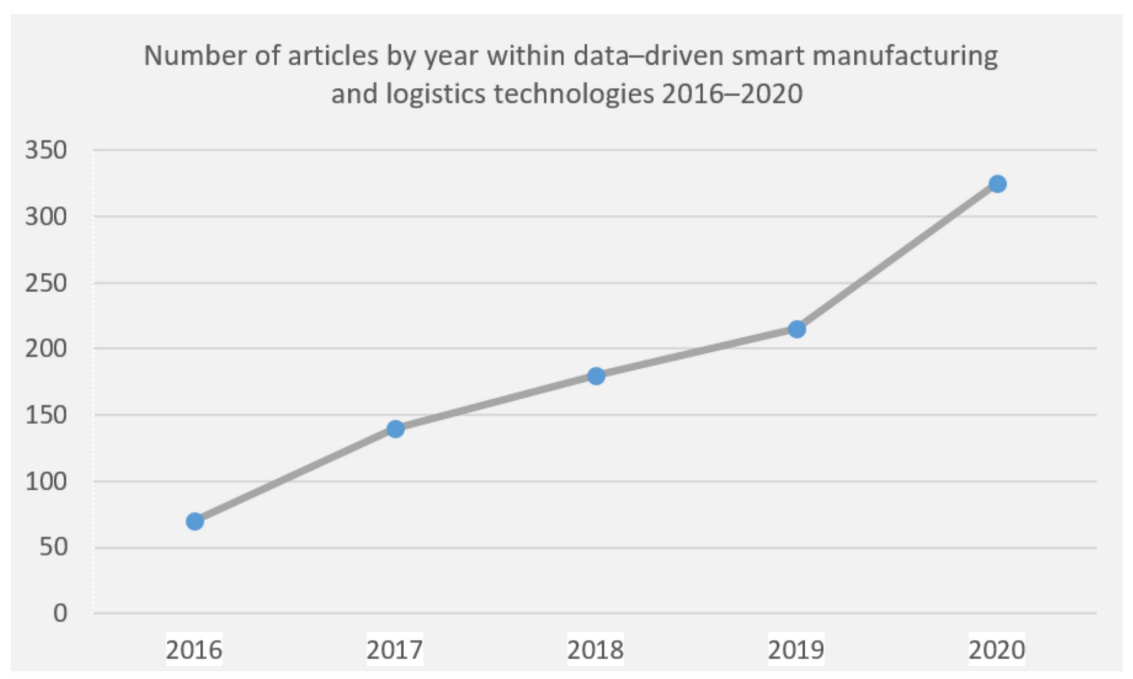

Figure 1. Number of articles by year within data-driven smart manufacturing and logistics technologies. 
In the next step, based on the criteria shown in Table 1, all the abstracts of 717 articles were screened and 544 articles excluded from the list. It is worth mentioning that there were many articles related to city logistics, transportation and manufacturing that have keywords in common with production logistics, but perceived as irrelevant and off-topic, and thus removed. The remaining 173 papers were picked for full paper reading. After full paper screening, 57 other papers were excluded from the list, as they did not match the inclusion criteria listed in Table 1. During the full paper review, a backward snowballsearch in the references of the relevant articles was carried out to search for further relevant articles; 26 new articles found in this step and added to the list. In total, 142 articles remained in the final list. Figure 2 illustrates the described steps.

Table 1. Inclusion and exclusion criteria.

\begin{tabular}{|c|c|c|}
\hline & Inclusions & Exclusions \\
\hline Production logistics & $\begin{array}{l}\text { Any research related to } \\
\text { internal logistics of production } \\
\text { or manufacturing companies. }\end{array}$ & $\begin{array}{l}\text { City logistics, cargos, road } \\
\text { transportations, machining, } \\
\text { assembly, product development, } \\
\text { retailing, production planning, } \\
\text { product design, maintenance, } \\
\text { housing construction. }\end{array}$ \\
\hline Enabling technologies & $\begin{array}{l}\text { Any relevant technologies that } \\
\text { might enable data collection, } \\
\text { data processing, data storage, } \\
\text { data streaming and data } \\
\text { analysis or data visualization. }\end{array}$ & $\begin{array}{l}\text { Automation technologies such } \\
\text { as introduction of robots that } \\
\text { are only focused on physical } \\
\text { aspects of the flow. }\end{array}$ \\
\hline $\begin{array}{l}\text { Production logistics } \\
\text { activities }\end{array}$ & $\begin{array}{l}\text { Any relevant activities such as } \\
\text { kitting, route planning, } \\
\text { warehousing, packaging, } \\
\text { material movement, which is } \\
\text { associated with enabling } \\
\text { technologies }\end{array}$ & $\begin{array}{c}\text { Mathematical modeling } \\
\text { optimization and data security. }\end{array}$ \\
\hline
\end{tabular}

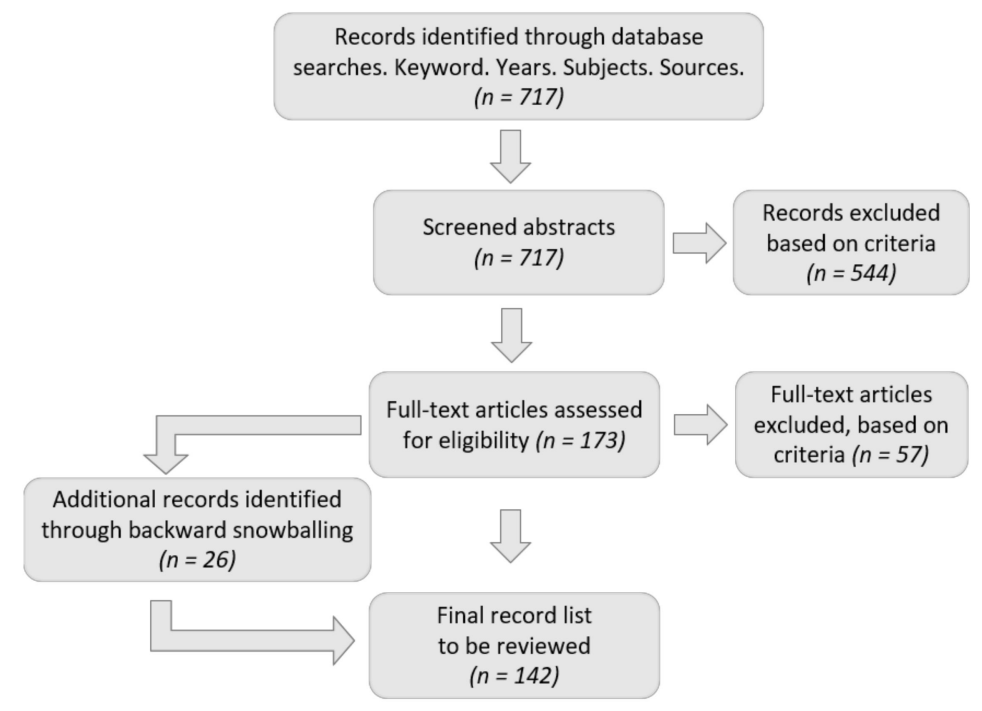

Figure 2. Systematic literature review steps in this research.

In order to minimize the risk of bias in the selection process, inclusion and exclusion criteria were developed, inspired by the PEO model (see [36]). Three main areas, including "production logistics", "enabling technologies" and "PL activities" were determined by the authors to examine inclusion and exclusion criteria. Table 1 shows these criteria. 
In addition to the mentioned criteria, all the selected papers needed to be of high quality with respect to:

- Clarified aims and RQs;

- Clarity in study design and method;

- Contribution to the research field;

- Connection to the research field;

- Good theoretical alignment, and data quality.

Figure 3 depicts the journals and respective number of articles that were analyzed in this review. It should be noted that the figure only illustrates journals that had more than one hit.

\section{Reviewed journals}

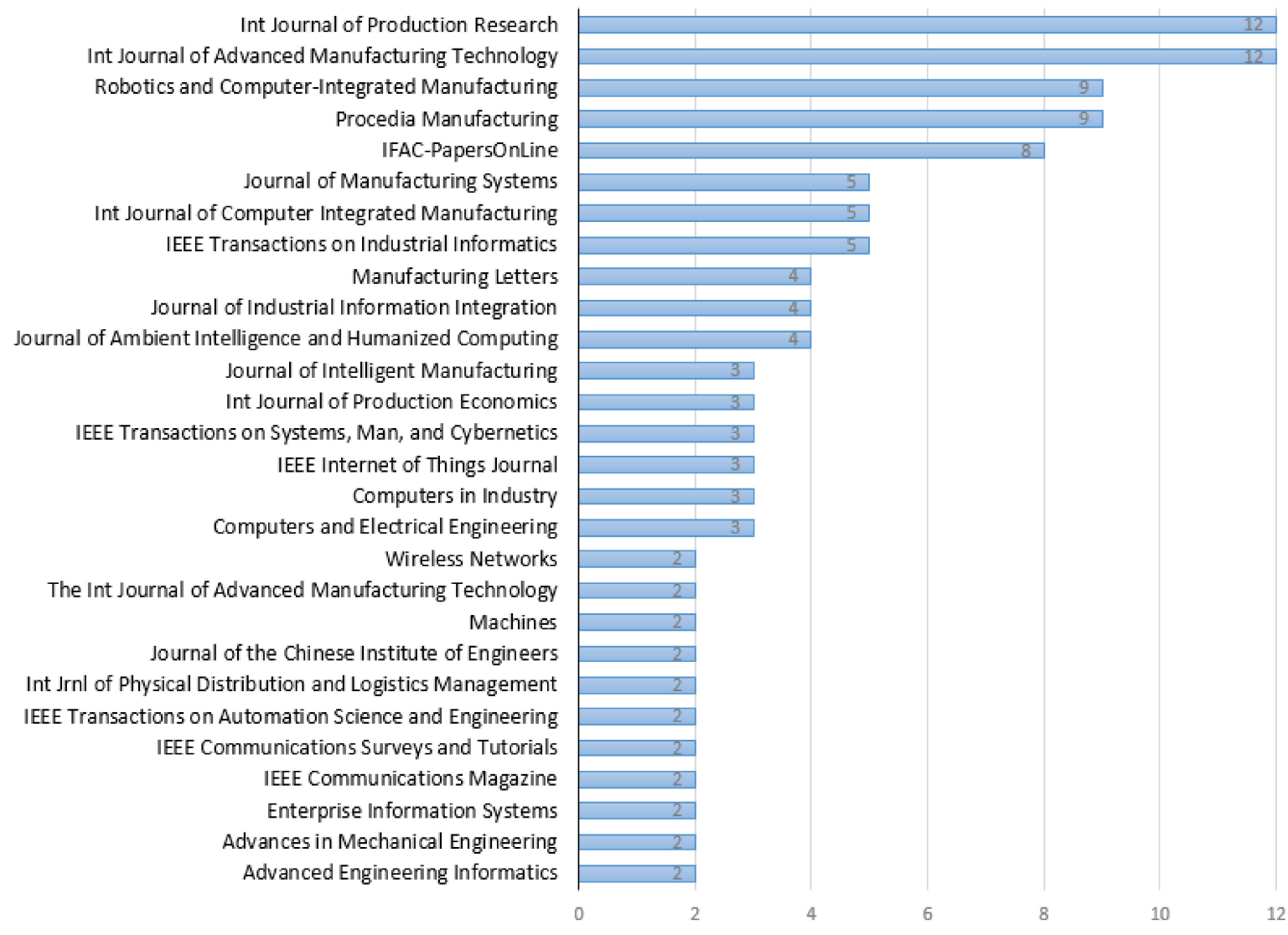

Figure 3. Reviewed journals with more than one article.

In total, 78 journals were included in the original 717 records in the SLR, whereof 50 of them had one article for further analysis. International journal of advanced manufacturing and International journal of production research have the highest number of articles in this review.

The next section is the third stage of the SLR, which is reporting and dissemination. Technologies and key activities (RQ1) identified in the full text screening and the discussion regarding value creation (RQ2) are presented in more details.

\section{Identified Technologies and Related Production Logistics Activities}

In the review of the 142 articles, 47 technologies were identified. These were divided into 10 groups based on their similarities and types. As explained in Section 1, each of the identified technologies belong to one of the three levels of technologies: device/component, methods or systems. For example, technologies for auto identification are devices, while embedded systems or IoT are perceived as system level technologies consisting of several 
technologies such as sensor networks, wireless connection and data analysis. Wireless communication protocols such as Wi-Fi, ZigBee or Bluetooth are methods, here also considered as technologies. Table 2 shows the identified technologies.

Table 2. Identified production logistics data-driven enabling technologies

\begin{tabular}{|c|c|}
\hline Technology Group & Technologies \\
\hline Auto Identification & $\begin{array}{c}\text { RFID (Radio Frequency Identification) } \\
\text { Barcode } \\
\text { QR code } \\
\text { FOT (Fingerprint of Things) and tag free traceability }\end{array}$ \\
\hline Vision systems and image processing & $\begin{array}{l}\text { Vision systems } \\
\text { Point cloud }\end{array}$ \\
\hline Mobile and industrial robots & $\begin{array}{c}\text { Industrial robots } \\
\text { Drones } \\
\mathrm{AGV} \text { and mobile robots }\end{array}$ \\
\hline $\begin{array}{l}\text { Internet-of-Things/ } \\
\text { Internet-of-Services }\end{array}$ & $\begin{array}{c}\text { IoT } \\
\text { IoS } \\
\text { RTLS (Real-Time Locating system) } \\
\text { Node-RED }\end{array}$ \\
\hline Smart devices & $\begin{array}{c}\text { AR (Augmented Reality) } \\
\text { VR (Virtual Reality) } \\
\text { Pick by X (Voice or light) } \\
\text { Smart glass } \\
\text { Smart gloves } \\
\text { Smart watches } \\
\text { Tablet, mobile phone, etc. }\end{array}$ \\
\hline Artificial intelligence and Big data & $\begin{array}{c}\text { BD analytics } \\
\text { AI } \\
\text { Machine learning } \\
\text { Apache Flume } \\
\text { Apache Hadoop } \\
\text { Apache Kafka } \\
\text { MQTT }\end{array}$ \\
\hline
\end{tabular}

Cellular networks $(2 \mathrm{G} / 3 \mathrm{G} / 4 \mathrm{G} / 5 \mathrm{G})$

Wireless connection

Bluetooth

Ultra sound

Ultrawide band

Wireless connection and communication networks

$$
\begin{gathered}
\text { Wi-Fi } \\
\text { ZigBee }
\end{gathered}
$$

Industrial communication networks

GPS (Global positioning system)

Industrial wireless networks Sensor networks

Cloud and Fog/Edge computing

Cyber physical systems and simulation
Cloud computing

Fog/Edge computing

\section{CPS}

Digital twin

Embedded systems

Holonic manufacturing and Multi agent systems

Simulation

SoA (Service Oriented Architecture) 
Based on the goal of this paper, enabling technologies found in literature were reviewed with respect to their application in PL activities. All these activities are in line with inclusion and exclusion specifications presented in Table 1 . The activities were categorized into three different groups as follows:

- Category 1: Shopfloor operational-related activities including activities that have a direct impact on material movement and material handling. The activities concern physical flow of material. In a PL system with a low level of automation and digitalization, usually these activities involve physical effort. From goods receiving until delivery to internal customers, all activates that involve direct contact with physical goods and material fall under this category.

- Category 2: Planning and scheduling-related activities are regarded as those logistics activities that are aimed to guide the overall operation, and make plans and schedules for an efficient production flow. While the first category concerns physical material flow, this category is about those activities that are known as planning and scheduling. Activities in this category are designed to assure PL system efficiency.

- Category 3: Control, track and trace-related activities are mainly focused on activities that monitor the behavior of logistics system elements such as resources, goods movement and inventory level. Activities in this category control the physical flow of material from items identification until conditions monitoring. This category is essential to increase efficiency of the activities in the two other categories.

For each of these categories, following sections and following tables depict production logistics activities and the data-driven enabling technologies identified in the reviewed literature.

\subsection{Category 1: Shopfloor Operational-Related Activities}

This category includes operational-related activities, including activities that have a direct impact on material movement and material handling. Usually these activities involve physical interaction with parts, raw material, machines, etc. For example, refilling material buffers, packaging, material-delivery to different working stations and kitting of material and parts for assembly. As presented in Table 3, each of the identified technologies are used for activities in one or several of the PL activities areas. Each of the identified technologies in the category "Described Technologies" in Table 3 belong to one of the three levels of technologies: device/component, methods and systems.

Table 3. Production logistics activities in Category 1 and association with the identified technologies in the literature.

\begin{tabular}{|c|c|c|c|c|}
\hline & $\begin{array}{l}\text { Production } \\
\text { Logistics } \\
\text { Activities }\end{array}$ & \multicolumn{2}{|c|}{ Described Technologies } & References \\
\hline \multirow[t]{2}{*}{$\begin{array}{c}\text { Category } 1 . \\
\text { Shopfloor operational- } \\
\text { related } \\
\text { activities }\end{array}$} & $\begin{array}{l}\text { Material ordering and } \\
\text { buffer replenishment }\end{array}$ & $\begin{array}{ll}\text { - } & \text { AGV and mobile } \\
\text { - } & \text { robots } \\
\text { Big data and BD } \\
\text { analytics } \\
\text { - } & \text { Cloud computing } \\
\text { - } & \text { Barcode } \\
\text { - } & \text { Vision system and } \\
\text { image processing } \\
\text { - } & \text { Sensor networks } \\
\text { - } & \text { Embedded } \\
& \text { systems }\end{array}$ & $\begin{array}{ll}\text { - } & \text { CPS } \\
\text { - } & \text { IoT } \\
\text { - } & \text { RFID } \\
\text { - } & \text { GPS } \\
\text { - } & \text { AI } \\
\text { - } & \text { Hadoop } \\
\text { - } & \text { QR code }\end{array}$ & $\begin{array}{c}{[10,12,15,22,28,35,37-} \\
60]\end{array}$ \\
\hline & $\begin{array}{l}\text { Goods receiving } \\
\text { quality control and } \\
\text { registration }\end{array}$ & $\begin{array}{ll}\text { - } & \text { Cloud computing } \\
\text { - } & \text { Edge computing } \\
\text { - } & \text { Vision system and } \\
& \text { image processing } \\
\text { - } & \text { Industrial robot }\end{array}$ & $\begin{array}{ll}- & \text { CPS } \\
\text { - } & \text { RFID } \\
\text { - } & \text { AR } \\
\text { - } & \text { Flume }\end{array}$ & {$[34,51,61-67]$} \\
\hline
\end{tabular}


Table 3. Cont.

\begin{tabular}{|c|c|c|c|}
\hline $\begin{array}{l}\text { Production } \\
\text { Logistics } \\
\text { Activities }\end{array}$ & \multicolumn{2}{|c|}{ Described Technologies } & References \\
\hline Kitting & - $\quad \mathrm{AR}$ & & {$[62]$} \\
\hline Packaging & $\begin{array}{ll}\text { - } & \text { Barcode } \\
\text { - } & \text { AGV and mobile } \\
\text { - } & \text { robots } \\
\text { CPS }\end{array}$ & $\begin{array}{ll}- & \text { RFID } \\
- & \text { AR } \\
\text { - } & \text { IoT }\end{array}$ & {$[10,14,36,62,68-70]$} \\
\hline Palletization & - $\quad \mathrm{AR}$ & & {$[62]$} \\
\hline $\begin{array}{l}\text { Picking and } \\
\text { Pick and place }\end{array}$ & $\begin{array}{ll}\text { - } & \text { Vision systems } \\
& \text { and image } \\
& \text { processing } \\
\text { - } & \text { AGV and mobile } \\
& \text { robots } \\
\text { - } & \text { Industrial robot } \\
\text { - } & \text { Digital twin } \\
\text { - } & \text { Cloud computing } \\
\text { - } & \text { Sensor networks }\end{array}$ & $\begin{array}{ll}\text { - } & \text { CPS } \\
\text { - } & \text { IoT } \\
\text { - } & \text { RFID } \\
\text { - } & \text { AR } \\
\text { - } & \text { Pick by X } \\
\text { - } & \text { Smart glass } \\
\text { - } & \text { Simulation }\end{array}$ & {$[10,14,62,65,69,71-82]$} \\
\hline $\begin{array}{l}\text { Material transportation } \\
\text { and internal } \\
\text { transportation } \\
\text { optimization }\end{array}$ & $\begin{array}{ll}\text { - } & \text { Vision systems } \\
& \text { and image } \\
& \text { processing } \\
\text { - } & \text { AGV and mobile } \\
& \text { robots } \\
\text { - } & \text { Digital twin } \\
\text { - } & \text { Edge computing } \\
\text { - } & \text { Cloud computing } \\
\text { - } & \text { Sensor networks } \\
\text { - } & \text { MAS and NEIMS }\end{array}$ & $\begin{array}{ll}\text { - } & \text { CPS } \\
\text { - } & \text { IoT } \\
\text { - } & \text { RFID } \\
\text { - } & \text { Simulation } \\
\text { - } & \text { AR } \\
\text { - } & \text { Industrial robot }\end{array}$ & $\begin{array}{c}{[12,13,15,34,40,62,71]} \\
{[72,74,75,77,83-103]}\end{array}$ \\
\hline Warehousing & $\begin{array}{ll}\text { - } & \text { Vision systems } \\
& \text { and image } \\
\text { - } & \text { processing } \\
& \text { AGV and mobile } \\
\text { - } & \text { robots } \\
\text { - } & \text { Industrial robot } \\
\text { - } & \text { Bigital twin data and BD } \\
& \text { analytics } \\
\text { - } & \text { Cloud computing } \\
\text { - } & \text { Edge computing } \\
\text { - } & \text { Sensor networks } \\
\text { - } & \text { MAS and NEIMS } \\
\text { - } & \text { Smart glass } \\
\text { - } & \text { Smart gloves } \\
\text { - } & \text { Smart watches } \\
\text { - } & \text { Tablet, smart } \\
& \text { phone, etc. }\end{array}$ & $\begin{array}{ll} & \\
\text { - } & \text { Point cloud } \\
\text { - } & \text { Block chain } \\
\text { - } & \text { Drone } \\
\text { - } & \text { CPS } \\
\text { - } & \text { AI } \\
\text { - } & \text { IoT } \\
\text { - } & \text { RFID } \\
\text { - } & \text { QR code } \\
\text { - } & \text { AR } \\
\text { - } & \text { Pick by X } \\
\text { - } & \text { VR } \\
\text { - } & \text { Barcode }\end{array}$ & $\begin{array}{c}{[10,14,27,28,43,45,46,49-} \\
53,58,62,63,68,71,73- \\
75,79,91,98,103-121]\end{array}$ \\
\hline
\end{tabular}

Some key examples from Table 3 of how technologies (device/component, methods or systems) were reported to be used in shopfloor operational related PL activities are described in the following.

Park et al. [37] designed and implemented a digital twin to address issues concerning dynamic situations of personalized production. One of the applications in their study was about the buffer handling process, which required constant monitoring of the buffer 
level. To meet the aim of the study, a CPS was designed and implemented and other technologies such as a collaborative robot. In a similar case, Thoben et al. [21] investigated a gear manufacturer working based on lean production, which is one of the first Industry 4.0 lighthouse projects in Germany. The CPS was established to increase the efficiency of the lean production. As a result, the buffer level was kept low despite high production variation. The delivery to production stations was based on demand-driven milk runs, which led to higher flexibility, a lower buffer level and dynamic scheduling. Load carriers were equipped with sensors that could monitor environmental parameters such as the temperature and acceleration. Operators had a PC to be able to communicate with the CPS to receive information regarding delivery or collection needs in real-time. Other IoT technologies such as auto-ID including RFID and QR codes can play a significant role to control buffer levels and WIP [12,37,38,107]. Trentesaux et al. [72] mentioned the possibility to solve issues such as inventory updates triggered by real-time events controlled in realtime based on service-orientated architecture (SOA) orchestration. In such a system, holons are used to act as an agent or a CPS to induce actions in the physical world.

Hohmann and Posselt [84] highlighted the effect of using CPS for goods registration in goods receiving as it can decrease the required time. To make sure that packages that arrive from suppliers have acceptable quality, vision inspection systems can be used to examine the dimension, shape, positioning and package orientation [61]. A ceiling camera can be used as a route-planning instrument to guide the AGV to transport different parts to different sections of the warehouse [74]. According to Egger and Masood [62], AR has the potential to be used for quality inspection by improving reaction speed and failure investigation. From a logistics perspective, parts may be investigated on the pallet as they arrive at goods receiving. Franceschini et al. [122] developed a prototype to do this task (Egger and Masood, 2020). Al-Jaroodi et al. [63] argued that edge computing can facilitate raw material quality control. Quality investigation data can be constantly communicated with other systems and provide an end-to-end integration amongst the existing systems. To make sure the right product has been received, vision systems can be used to monitor parameters such as dimensions, object ID, supplier ID, etc. [65,66].

To prepare kits for mixed-model assembly through order picking, Egger and Masood [62] mentioned that AR technology can be superior to conventional paper-based methods.

According to Sarupuri et al. [123], AR has the potential to help operators to have better performance in warehouses with high-rack storage [62]. Besides, according to experiments handled by the Fraunhofer Institute for Material Flow and Logistics in Dortmund, Germany, AR has the potential to be used in packaging and palletization [62], as the packaging speed and use of the space are improved [124].

By using $5 \mathrm{G}$, it will be possible to have an efficient infrastructure for a smart storage system as it can accelerate the communication amongst system components [104].

Chen [46] argued that RFID can realize warehouse automation through electronic tags and stackers to manage warehouse scheduling and inventory highly intelligently. As an example, RFID technology can be used to register the incoming and outgoing flow of products into the warehouse environment [49] or to manage the expiration dates of products [51]. Chen et al. [98] highlighted the potential of CPS to support the idea of smart warehouses. According to Damiani et al. [105], AR and VR have the potential to be used to train warehouse operators to increase the quality of operators' interactions with their environment. Chung et al. [50] argued that a block chain has the potential to facilitate distributed, transparent, safe and scalable processes compared to centralized processes. For example, warehouse carry-in, warehouse load and warehouse carry-out processes can benefit from a block chain as the real-time trade transactions data can be analyzed to draw meaningful rules and have efficient decision-making. Culler and Long [74] introduced a smart warehouse project, where vision systems such as Kinect cameras were mounted on an AGV for obstacle avoidance. The main task for the AGV was to transport items within the warehouse environment. Semwal et al. [103] also introduced a CPS-based testbed warehouse where AGVs communicate with racks equipped with 
embedded boards with sensors. The communication amongst smart entities happens over Wi-Fi. Avventuroso [106] developed a digital twin system based on IoT to mimic warehouse operation. The results have proven that the decision-making process is more efficient. Bortolini et al. [52] argued that use of sensor networks in workstation storage helps to reduce the WIP inventory level as the system can adjust the replenishment request to the central warehouse according to the real-time data collected from the workstation storage. Within a CPS-based material handling system, data mining, predictive analytics and smart algorithms can be used in cloud or edge computing services for warehouse management and supply chain value [63]. Liao et al. [75] proposed a smart factory prototype where delivery orders from the cloud centre are sent to AGV to transport empty product containers from warehouses to production lines for further operation. Each of the product containers is equipped with an RFID tag, which retrieves data for that specific product from a cloud system through IoT. Zhong et al. [44] investigated a case study where RFID was used as a means to support warehouse management. As the warehouse manager finished with the logistics planning, raw materials were identified and prepared for delivery in the warehouse. In the next step, an operator got instructions over a mobile RFID reader to locate the required materials and transport them from the warehouse to machine buffers. The connections happened over an IoT-enabled network. Some other similar cases used RFID/QR codes in warehouse management mentioned in the table above. To manage warehouse operations including material movement, Zhang et al. [110] implemented a cloud-based smart system. Apart from other applications, operators were equipped with various types of handheld terminals such as tablets connected to a "warehouse management software database" through a web service in real-time. As a result, logistics activities were triggered automatically and the data was circulating constantly amongst the warehouse, WMS, managers and operators.

Gregor et al. [125], Lu et al. [89] and Liu et al. [86] highlighted the role of AGVs as they can receive orders and relevant data from the CPS to complete material movement tasks. Wang et al. [91] described a system where an AGV was equipped with an RFID reader to read and write data to the products' RFID tags. Researchers have mentioned the role of mobile robots supplied with real-time data to perform material movement and internal transportation of parts and materials [13,74,87,90,92-94,96,97,102]. Szafir et al. [102] did experiments with drones to locate misplaced boxes in a warehouse environment. $\mathrm{Li}$ et al. [60] described how industrial wireless networks along with cloud computing and big data can support smart manufacturing. Part of their work focused on material movement through a conveyor system connected to a cloud server and controlled in real-time for product transportation. Müller et al. [126] highlighted the role of sensor networks to collect real-time information from production, communicate with cyber systems and, after being analyzed by algorithms, transfer it back to physical equipment, in this case a conveyor system. To facilitate the connection with the operators responsible for material handling, devices such as tablets can be used. Tablets are connected to the CPS that collects data in real-time by means of RFID tags [94]. Beside, artificial intelligence application has been highlighted by Lee et al. [127]. Gröhn et al. [101] explored an automated system benefit of RIFD and sensor networks to control the conveyor system to transport materials across a production facility. CPS can be used to facilitate a highly flexible demand-driven material flow through simulation as data collection happens through technologies such as RFID tags and an electronic Kanban system [35]. Liao et al. [75] described a smart factory testbed built by Lego based on holonic manufacturing principles. Each holon has the possibility to make decisions and interact with other holons by having equivalent decision levels. One of the applications of the smart factory testbed in their experiment was autonomous decision-making regarding transportation of empty product containers between working stations.

Pick by vision can be used to indicate the picking location and picking quantities [62]. Smart glasses can be used to pick parts from a shelf as the glass can read the barcode and the operator has free hands to do the picking activities [71]. Costanzo et al. [73] 
developed a point cloud environment where a collaborative robot could perform pick and place activities for in-store logistics scenarios with application in warehouses. Liao et al. [75] used a collaborative robot that received data from an IoT-based system equipped with a Raspberry Pi transmitting the destination place. The robot picked the object and placed it into the address received from the Raspberry Pi. In another similar case, Stark et al. [76] discussed the use of a digital twin for pick and place activities handled by robots. A Raspberry Pi was connected to sensors and actuators that communicated with the picking robot over Wi-Fi. Microcontrollers translated the commands for the picking robot. Lee et al. [14] tested a framework built upon an IoT-based WMS aiming to optimize order picking. Ramakrishnan et al. [128] used IoT beacons to manage shopfloor inventory leading to improved order picking. Wang et al. [78] analyzed an AR application in parts picking from storage. The operator received orders, locations and picking quantities through AR. In a case study by Meng et al. [69] in food manufacturing, RFID was used to form an IoT-based system, in which a robot picked raw materials from input crates and placed them inside empty food packages. In another case by Leung et al. [80], a cloud-based database was developed to support e-order consolidation and parts picking from storage. Kembro et al. [65] mentioned that vision systems and image processing can support picking activities by controlling whether the object is removed from its location or not.

\subsection{Category 2: Planning and Scheduling-Related Activities}

This category includes planning and scheduling-related activities, regarded as those logistics activities that are aimed to guide the overall operation, and make plans and schedules for an efficient production flow. Planning and scheduling of deliveries, layout planning and delivery route planning are some of the examples. As presented in Table 4, each of the technologies has an application in one or several of the PL activities areas. Each of the identified technologies belong to one of the three levels of technologies namely device or component, methods, and systems.

Table 4. Production logistics activities in Category 2 and association with the identified technologies in the literature.

\begin{tabular}{|c|c|c|c|c|}
\hline & $\begin{array}{l}\text { Production } \\
\text { Logistics } \\
\text { Activities }\end{array}$ & \multicolumn{2}{|c|}{ Described Technologies } & References \\
\hline $\begin{array}{l}\text { Category } 2 . \\
\text { Planning and } \\
\text { scheduling- } \\
\text { related } \\
\text { activities }\end{array}$ & $\begin{array}{l}\text { Logistics resource } \\
\text { planning }\end{array}$ & $\begin{array}{ll}\text { - } & \text { Vision systems } \\
& \text { and image } \\
& \text { processing } \\
\text { - } & \text { Digital twin } \\
\text { - } & \text { Big data and BD } \\
& \text { analytics } \\
\text { - } & \text { Cloud computing } \\
\text { - } & \text { MAS and NEIMS }\end{array}$ & $\begin{array}{ll}\text { - } & \text { CPS } \\
\text { - } & \text { Hadoop } \\
\text { - } & \text { IoT } \\
\text { - } & \text { RFID } \\
\text { - } & \text { Barcode }\end{array}$ & $\begin{array}{c}{[10,22,44,48,50,53,55,67,} \\
68,84,85,97,104,107,110 \\
113,129-131]\end{array}$ \\
\hline
\end{tabular}


Table 4. Cont

\begin{tabular}{|c|c|c|c|}
\hline $\begin{array}{l}\text { Production } \\
\text { Logistics } \\
\text { Activities }\end{array}$ & \multicolumn{2}{|c|}{ Described Technologies } & References \\
\hline Route planning & $\begin{array}{ll}\text { - } & \text { Vision systems } \\
\text { and image } \\
\text { processing } \\
\text { - } & \text { AGV and mobile } \\
\text { robots } \\
\text { - } & \text { Big data and BD } \\
\text { analytics } \\
\text { - } & \text { Holonic } \\
\text { manufacturing } \\
\text { - } & \text { MAS and NEIMS } \\
\text { - } & \text { Cloud computing } \\
\text { - } & \text { Edge computing }\end{array}$ & $\begin{array}{ll}- & \text { CPS } \\
- & \text { AI } \\
- & \text { Barcode } \\
- & \text { IoT } \\
- & \text { RFID } \\
- & \text { Digital twin } \\
- & \text { Sensor networks }\end{array}$ & $\begin{array}{l}{[10,12,13,49,61,67,74,83,} \\
84,115,119,129,131-138]\end{array}$ \\
\hline $\begin{array}{l}\text { Delivery planning and } \\
\text { scheduling }\end{array}$ & $\begin{array}{ll}\text { - } & \text { AGV and mobile } \\
& \text { robots } \\
\text { - } & \text { Big data and BD } \\
& \text { analytics } \\
\text { - } & \text { Digital twin } \\
\text { - } & \text { Cloud computing } \\
\text { - } & \text { Tablet, smart } \\
\text { - } & \text { phone } \\
\text { - } & \text { Edge computing } \\
\text { - } & \text { manufacturing } \\
\text { - } & \text { Sensor networks } \\
\text { - } & \text { MAS and NEIMS }\end{array}$ & $\begin{array}{ll}\text { - } & \text { Barcode } \\
\text { - } & \text { AI } \\
\text { - } & \text { CPS } \\
\text { - } & \text { IoS } \\
\text { - } & \text { RFT } \\
\text { - } & \text { RTLS } \\
\text { - } & \text { QR code } \\
\text { - } & \text { Pick by } X\end{array}$ & $\begin{array}{c}{[10,15,38-40,44,45,48,} \\
54,63,86,93,98,106,112, \\
113,115,116,129,132- \\
135,137,139,140]\end{array}$ \\
\hline Workflow analysis & $\begin{array}{ll}\text { - } & \text { Vision systems } \\
& \text { and image } \\
& \text { processing } \\
\text { - } & \text { Big data and BD } \\
\text { analytics } \\
\text { - } \quad \text { Cloud computing } \\
\text { - } \quad \text { Machine learning } \\
\text { - } \quad \begin{array}{l}\text { Big data and BD } \\
\text { analytics }\end{array}\end{array}$ & $\begin{array}{ll}\text { - } & \text { Hadoop } \\
\text { - } & \text { IoT } \\
\text { - } & \text { RFID } \\
& \text { Flume }\end{array}$ & {$[40,44,53,65,83,85,119]$} \\
\hline $\begin{array}{l}\text { Modeling and } \\
\text { simulation }\end{array}$ & $\begin{array}{ll}\text { - } & \text { AGV and mobile } \\
& \text { robots } \\
\text { - } & \text { Big data and BD } \\
\text { analytics } \\
\text { - } & \text { Embedded } \\
& \text { systems } \\
\text { - } & \text { Digital twin }\end{array}$ & $\begin{array}{ll}- & \text { IoT } \\
- & \text { RFID } \\
- & \text { AR }\end{array}$ & {$[48,72,141]$} \\
\hline $\begin{array}{l}\text { Layout planning and } \\
\text { optimization }\end{array}$ & $\begin{array}{ll}\text { - } & \text { Big data and BD } \\
\text { analytics } \\
\text { - } & \text { Simulation }\end{array}$ & $\begin{array}{ll}\text { - } & \text { RFID } \\
& \text { VR }\end{array}$ & {$[119,142]$} \\
\hline
\end{tabular}

Some key examples from Table 4 of how technologies (device/component, methods or systems) were reported to be used in planning and scheduling-related PL activities are described in the following.

Al-Jaroodi et al. [63] argued that by integrating the services of manufacturers, suppliers and transportation systems, it is possible to optimize raw material delivery scheduling. To realize the integration, forming a CPS-based system that collects data from the shopfloor in 
combination with data analytics techniques is necessary. Chen et al. [98] developed a CPS for circuit breaker production. In their case, multisource heterogeneous data was constantly collected from production lines. From a production logistics perspective, big data analytics can be used to do intelligent material assignment. In a similar case, Zhong et al. [44] proposed using RFID and wireless communication to support big data analytics aimed to have several managerial implications including logistics planning and scheduling. The role of big data analytics also highlighted for PL planning and scheduling has been highlighted within smart factory context $[143,144]$. Hopkins and Hawking [116] mentioned pick up and delivery window planning as one of the big data analytics applications. Mahroof [115] investigated AI adoption in warehouse management and highlighted the importance of managing flexible planning techniques supporting long-range planning through matching short-term and long-term goals. Ding et al. [48] proposed a digital twin-based CPS for smart manufacturing. Part of their job focused on resource scheduling including logistics. They used an RFID tag, an embedded system device and a travelling pallet that were configured to each part or each batch of parts. As the parts became intelligent, they had the ability to communicate with the surrounding area through connectivity means such as Wi$\mathrm{Fi}$, Bluetooth and Zigbee. To deal with synchronization of logistics and production caused by high fluctuating demands, Qu et al. [131], Zhang et al. [110] and Hwang et al. [145] used IoT and cloud. Yu [146] developed a system benefit from IoT and GIS and witnessed improvements in logistics planning (adopted from [10]). Zhang et al. [110] proposed a method to improve the synchronization between production and warehouses. The system was built upon IoT and RFID tags and QR tags were used to collect the constant flow of data. Warehouse operators were equipped with tablets as forklift drivers were constantly updated with location information through their tablets. Consequently, any change in the production plan was communicated to the warehouse through IoT. Some other authors such as Zhuang et al. [147], Semunab et al. [139], Qu et al. [134] and Qu et al. [131] also suggested using RFID as a representative of IoT for planning and scheduling related activities. Zhang et al. [133] developed an active sensing system of real-time and multisource manufacturing information. Part of the architecture of the system was dedicated to material delivery. In the system, RFID and sensor networks had a central role and communication benefitted from a wireless connection. Kamagaew et al. [148] discussed the role of MAS in delivery planning using 50 different unmanned vehicles in a research project. The vehicles autonomously sought for their tasks and moved in the research hall. The system capacity adjusted depending on seasonal fluctuations as agents were capable of communicating with each other and other systems that controlled the planning and scheduling (adopted from [135]). A similar case regarding a MAS application for planning and scheduling was highlighted by Leusin et al. [140]. Sicari et al. [54] did an IoT-based case study for smart transport logistics where smart vehicles in combination with RFID tags and RFID scanners were used to complete the material ordering process within a warehouse environment. Node-RED was used to manage the ordering data flow, warehouse data flow, RFID scanner data flow and smart vehicle data flow.

Regarding resource planning, according to Chung et al. [50], cognitive manufacturing requires IoT technology to collect data and technologies such as Hadoop to analyze big data collected from multiple sources. Accordingly, one of the main goals of such a system is to minimize the human resource utilization rate. Da Silva et al. [97] highlighted the role of big data in resource planning. In addition to other technologies mentioned in Table 3, Zhang et al. [129] and Trappey et al. [53] discussed cloud computing as one of the main enablers for effective resource planning as data is updated and available in real-time.

As described by Frank et al. [28] adopted from Gilchrist [149], AI in combination with an ERP system can be used to predict long-term production demands and transform them to daily production orders. As a result, the raw material order volume will be more precise.

Using auto-ID technologies such as RFID in production lines can help to have a more accurate demand assessment. Besides, Kanban bins might be equipped with sensors capable of tracking fill rates. This can form a CPS, which at the end helps to have an 
effective material ordering system [34,150]. Dai et al. [49] highlighted the role of big data in material ordering as a large amount of data collected from the shopfloor may be used to analyze the consumption rate and predict the order point.

According to Cui et al. [141] a digital twin can play a central role to simulate the logistical processes in order to provide real-time bidirectional management between a physical object and its digital twin. Ding et al. [48] mentioned that a digital twin can help to optimize resource allocation and relevant planning in manufacturing processes including PL.

Cao et al. [12] adopted from Kim et al., [151], Dai et al. [49] and Zhang et al. [96] proposed methods for route planning and navigation by employing RFID technology. Position data from the shopfloor was collected in real-time and facilitated route planning and traffic management in a shopfloor environment. To transport parts, materials and machines, different means such as automated driving technology were already in use in production areas. Zhang et al. [129] suggested the use of AGVs that navigate based on machine learning techniques. Similar to this, Wan et al. [13] and Qu et al. [134] highlighted the role of using intelligent AGVs for route planning and logistics navigation. According to Winkelhaus and Grosse [10], Yang et al. [152] developed an architecture of a cloud platform for intelligent logistics management including logistics navigation. Mahroof [115] investigated the role of $\mathrm{AI}$ in warehouse management and route planning within a warehouse environment by controlling the amount of travel time in the warehouse. Zhang et al. [96] described a system consisting of several AGVs communicating via RFID and a ZigBee network to perform route planning and collision avoidance.

According to Trappey et al. [153], IoT can have a significant role in logistics workflow analyses by employing related technologies such as RFID, WSN and cloud computing bases for data collected in real-time. Huang et al. [83] argued that deploying IoT technology increases visibility and traceability in production processes. Data collected from the shopfloor can be used to have precise bottleneck prediction and further helps to have proactive dispatching based on the future bottleneck. Zhong et al. [44] introduced big data analytics for physical internet-based logistics data from a smart shopfloor equipped with RFID tags and wireless communication networks. The logistics trajectory was visualized through big data analytics aiming to evaluate the efficiency of logistics operators and operations through the defined behaviors and KPIs. The evaluation results could be used as managerial guidance for efficient decision-making.

According to Huang et al. [83], by analyzing RFID logistics data through a big data approach, logistics trajectories can be discovered for shopfloor layout optimization. Turner et al. [142] reviewed the possibility of using discrete event simulation (DES) and virtual reality in industry. In this respect, one of the areas was layout optimization, which had the potential to be investigated further to benefit from DES and VR technology.

\subsection{Category 3: Control, Track and Trace-Related Activities}

This category includes control, track and trace-related activities, mainly focused on activities that monitor the behavior of logistics system elements such as resources, goods movement and inventory level. These activities control whether the operation is following the plans and schedules in a reactive manner and has the possibility to be done proactively to help the system to adjust its behavior in line with the latest changes. As presented in Table 5, each of the technologies has an application in one or several of the PL activities areas. Each of the identified technologies belong to one of the three levels of technologies namely the device or component, methods and systems. 
Table 5. Production logistics activities in Category 3 and association with the identified technologies in the literature.

\begin{tabular}{|c|c|c|c|c|}
\hline & $\begin{array}{l}\text { Production } \\
\text { Logistics }\end{array}$ & \multicolumn{2}{|c|}{ Described Technologies } & References \\
\hline \multirow[t]{3}{*}{$\begin{array}{l}\text { Category } 3 . \\
\text { Control, track and } \\
\text { trace } \\
\text { related activities }\end{array}$} & Items identification & $\begin{array}{ll}\text { - } & \text { Vision system and } \\
\text { - } & \text { image processing } \\
& \text { robots and mobile } \\
\text { - } & \text { Sensor networks } \\
\text { - } & \text { Big data and BD } \\
& \text { analytics } \\
\text { - } & \text { Cloud computing } \\
\text { - } & \text { Edge computing } \\
\text { - } & \text { Embedded system } \\
\text { - } & \text { FOT and tag-free } \\
& \text { traceability }\end{array}$ & $\begin{array}{ll}\text { - } & \text { CPS } \\
\text { - } & \text { QR code } \\
\text { - } & \text { IoT RFID } \\
\text { - } & \text { Barcode } \\
\text { - } & \text { Digital twin }\end{array}$ & $\begin{array}{c}{[12,14,15,19,27,37,43,46-} \\
49,52,54,58,65,67,69,75,84, \\
90,91,98,104,107,109,119- \\
121,131,132,140,154-161]\end{array}$ \\
\hline & $\begin{array}{l}\text { Items positioning } \\
\text { (localization) }\end{array}$ & $\begin{array}{ll}\text { - } & \text { Vision system and } \\
\text { image processing } \\
\text { - } & \text { AGV and mobile } \\
\text { - } & \text { robots } \\
& \text { Big data and BD } \\
\text { - } & \text { Edgatytics } \\
\text { - } & \text { Cloud computing } \\
\text { - } & \text { Cellular networks } \\
\text { - } & \text { Ultrasound } \\
\text { - } & \text { Ultra-wideband } \\
\text { - } & \text { Embedded } \\
& \text { systems } \\
\text { - } & \text { Sensor networks } \\
\text { - } & \text { Bluetooth }\end{array}$ & $\begin{array}{ll}\text { - } & \text { Barcode } \\
\text { - } & \text { CPS } \\
\text { - } & \text { Digital twin } \\
\text { - } & \text { GPS } \\
\text { - } & \text { WG } \\
\text { - } & \text { Zigbi } \\
\text { - } & \text { IoT } \\
\text { - } & \text { RFID } \\
\text { - } & \text { RTLS } \\
\text { - } & \text { QR code }\end{array}$ & $\begin{array}{r}{[10,12,15,19,37,43,46,48} \\
54,58,64,67,69,72,74,75 \\
82-84,86,89,98,104,107 \\
109,111,114,119,121,132 \\
140,141,150,159,161-166]\end{array}$ \\
\hline & Items tracing (flow) & 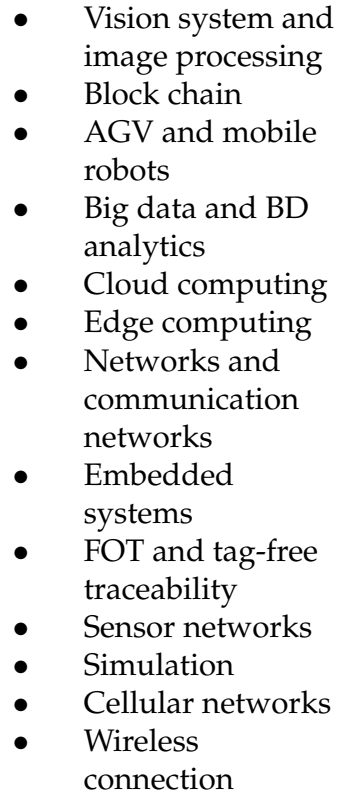 & $\begin{array}{ll}\text { - } & \text { Barcode } \\
\text { - } & \text { CPS } \\
\text { - } & \text { Digital twin } \\
\text { - } & \text { Hadoop } \\
\text { - } & \text { Wi-Fi } \\
\text { - } & \text { Zigbee } \\
\text { - } & \text { IoT } \\
\text { - } & \text { RFID } \\
\text { - } & \text { QR code } \\
\text { - } & \text { Pick by X } \\
\text { - } & \text { 5G } \\
\text { - } & \text { Bluetooth }\end{array}$ & $\begin{array}{c}{[5,10,12,14,15,19,27,34,43,} \\
45,46,48,49,51,53,56,58,64, \\
65,67-69,72,74,76,82,83 \\
98,104,107,109,111,119- \\
121,134,139-141,154- \\
158,160,163,165-172]\end{array}$ \\
\hline
\end{tabular}


Table 5. Cont.

\begin{tabular}{|c|c|c|c|}
\hline $\begin{array}{c}\text { Production } \\
\text { Logistics } \\
\text { Activities }\end{array}$ & \multicolumn{2}{|c|}{ Described Technologies } & References \\
\hline $\begin{array}{l}\text { Inventory level } \\
\text { controlling }\end{array}$ & $\begin{array}{ll}\text { - } & \text { Vision systems } \\
& \text { and image } \\
& \text { processing } \\
\text { - } & \text { Block chain } \\
\text { - } & \text { AGV and mobile } \\
& \text { robots } \\
\text { - } & \text { Big data and BD } \\
& \text { analytics } \\
\text { - } & \text { Cloud computing } \\
\text { - } & \text { Sensor networks } \\
\text { - } & \text { Simulation } \\
\text { - } & \text { Machine learning }\end{array}$ & $\begin{array}{ll}\text { - } & \text { Barcode } \\
\text { - } & \text { CPS } \\
\text { - } & \text { Digital twin } \\
\text { - } & \text { AI } \\
\text { - } & \text { IoT } \\
\text { - } & \text { RFID } \\
\text { - } & \text { SoA } \\
\text { - } & \text { Pick by X }\end{array}$ & $\begin{array}{c}{[10,12,14,15,27,34,38,41,} \\
49-52,54,56,57,59,67,72, \\
76,97-99,104,109,115, \\
116,119,121,139,141,155, \\
156,161,173-177]\end{array}$ \\
\hline $\begin{array}{l}\text { Items condition } \\
\text { monitoring }\end{array}$ & 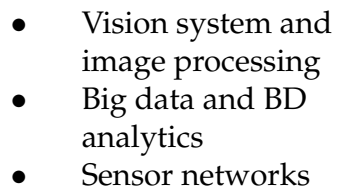 & $\begin{array}{ll}- & \text { RFID } \\
- & \text { IoT }\end{array}$ & {$[53-55,67,70,121,170]$} \\
\hline
\end{tabular}

Some key examples from Table 5 of how technologies (device/component, methods or systems) were reported to be used in control, track and trace related activities PL activities are described in the following.

To monitor items' conditions such as temperature, humidity, vibration, etc., several technologies have been mentioned by researchers. According to Zhang et al. [70], RFID biosensor tags can be used for history checking, contamination warnings and status tracking. The biosensor tags monitor antigens-antibodies to detect bacteria. Similar cases to monitor environmental parameters by means of RFID sensors were reported by $[54,67,121]$. Tao and Qi [55] mentioned that by using smart chips, environmental data can be collected and uploaded to the cyber world. With big data, the cyber section can analyze any changes in product conditions. La Scalia et al. [170] proposed a system to use smart sensors to monitor the temperature, humidity, $\mathrm{CO}_{2}$ and volatile organic compounds (VOCs). Apart from the sensors, cloud computing and GPS are other technologies that support real-time condition monitoring of perishable products. Trappey et al. [53] mentioned that WSN can be used in cold-chain logistics to monitor brightness, humidity, temperature, pressure and sound.

For items identification, items positioning and items tracing, one of the most cited technologies is RFID, as the references listed in Table 3. In some cases, RFID has been regarded as part of IoT and CPS technologies since it creates most of its value through connections with other logistics systems such as ERP, WMS, etc. [14,84,109,119]. Lai et al. [166] mentioned that many researchers have worked on finding accurate object location within an indoor environment with the help of different interfaces including $\mathrm{Wi}-\mathrm{Fi}$, Bluetooth, ZigBee, UWB, ultrasound, etc., and RFID as one of the main technologies. As mentioned by Zhang et al. [70], RFID can be a subsystem for technologies like block chains. Block chain implementation assists factories, distribution centers and retailers to trace their items from the very beginning until the final stages. Cui et al. [141] did a literature review and the results showed that almost $25 \%$ of big data applications concern monitoring. Cloud computing and sensor networks are two main technologies discussed by Mehmood et al. [58], as they can enable machine-to-machine communication amongst logistics equipment and machines. The communication amongst different machines and systems relies on cellular 
networks to facilitate mobility. Wigger et al. [157] investigated the possibility of tracing and identification of printed circuit boards (PCB) through fingerprint-of-things (FOT), in this case surface pattern photography. Fiducial markers would be soldered onto 115 PCBs by solder paste screen printing. Each soldered PCB would have unique identification. Using image processing technology, each of the PCBs would be uniquely tracked and identified. Similar cases have been reported for other materials such as paper, plastic, cork and metal [158]. Meroni et al. [155] designed an IoT-based monitoring platform to improve multipart business process monitoring. To meet the goal of their research, smart objects were used to share processed data in real-time. Objects equipped with smart sensors interacted via usual communication means such as Wi-Fi and $4 \mathrm{G}$. The communication amongst smart objects followed the MQTT protocol suitable for a low bandwidth and resource constraint environment. Zhong et al. [107] used laser scanner and image processing technologies in addition to RFID. RFID tags helped to identify the objects and the laser scanner was used to observe the movement of resources in the production area. Kembro et al. [65] also highlighted the role of vision systems for object identification and visual goods tracking. In addition to the benefits of CPS to trace items, it is important to have reliable and near real-time communication technologies such as 5G. The reason is that current industrial standards have limited capacity to support constant streaming of large amounts of captured data such as videos [163,178]. Cannizzaro et al. [162] mentioned Wi-Fi and Bluetooth Low Energy (BLE) as technologies that facilitate indoor positioning. In line with their argument, implementing $\mathrm{Wi}$-Fi requires effort in terms of topological distribution and the number of Wi-Fi access points, which increase costs and power consumption. On the other hand, BLE is suitable for short-range energy-efficient communication and compatible devices can transmit periodic messages. Chen et al. [98] proposed a CPS framework for smart manufacturing. The system benefits from AGVs, sensor networks and IoT technologies for production logistics activities. The AGV and RFID tags constantly update the digital twin with positioning and identification data. Data are transmitted over a cloud and shared with other subsystems in real-time.

\section{Discussion}

The identified technologies and their association with major PL activities are presented in Section 3. However, in order to further elaborate on RQ2, it is needed to determine on what level each of the technology groups are associated with PL activities categories. Besides, value creation as the main concern of any technological development need to be further analyzed. The following describes these concerns in more details.

\subsection{Share Assessment of the Identified Technologies}

Considering the technology grouping presented in Table 2, Figure 4 illustrates the share of each technology group within each PL activities category discussed in the literature. For instance, in $21 \%$ of the cases, "Auto Identification" technologies was mentioned as the data-driven enabling technology that has an application in production logistics. 


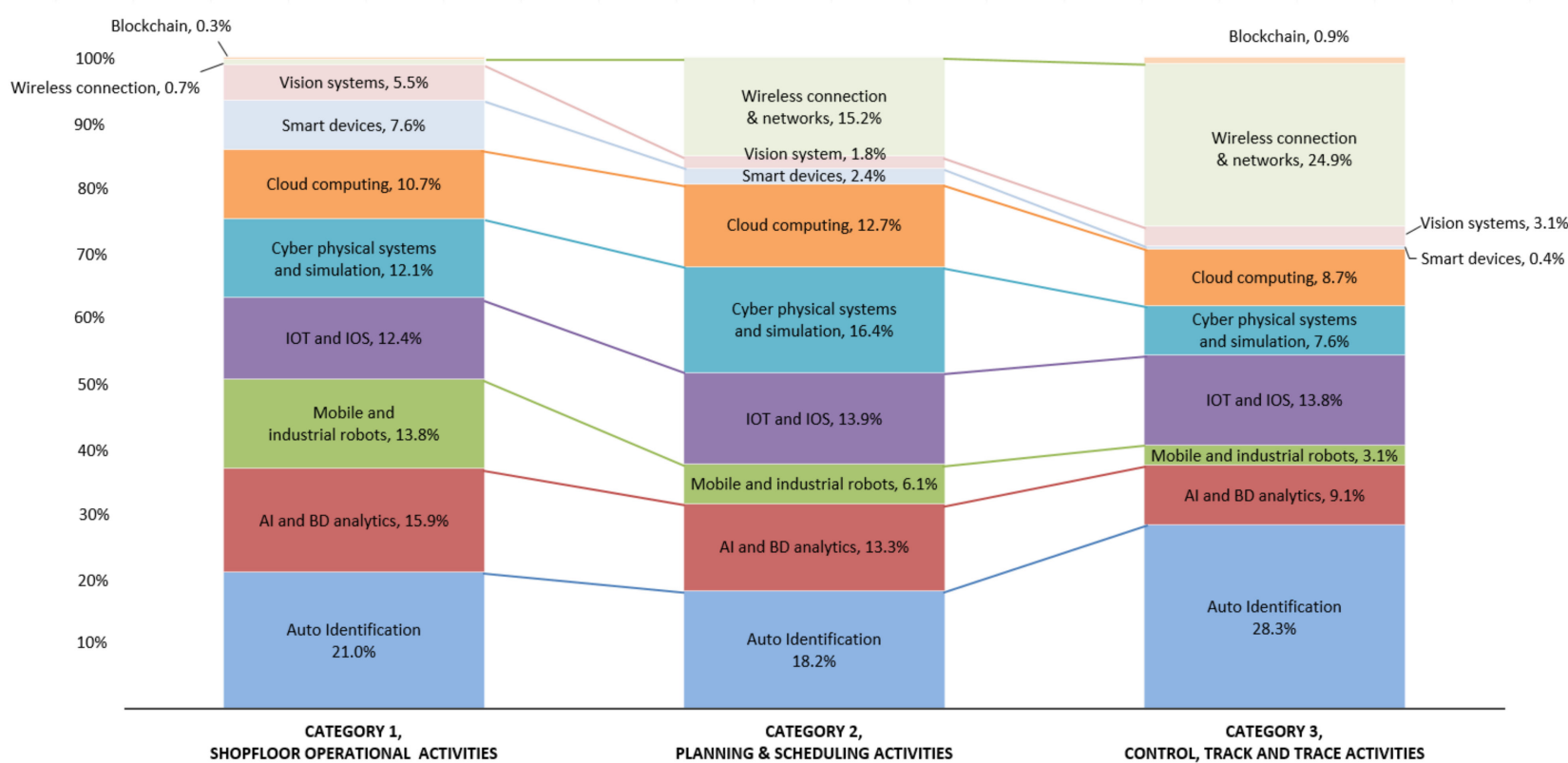

Figure 4. Share of the identified technologies supporting production logistics (PL) activities.

In the literature, autoidentification technologies have the highest share among the technologies for all three categories. Auto-id technologies have the most hits for category 3 in the literature, with $28 \%$ of articles on category 3 describing Auto-id solutions. In many cases auto identification technologies are mentioned alongside other types of technologies such as IoT or mobile robots in order to support a working process like material ordering. For category 2 and 3, much of the literature mentioned the importance of using technologies such as RFID as the preferred data collection method to perform activities such as real-time tracking, delivery planning and items historical condition monitoring. In some cases, auto-id technologies are part of a bigger technological system such as the block chain. Nevertheless, the literature review suggests that auto-id technologies can be applied either as a stand-alone technology or as a subsection of a bigger solution such as IoT or CPS. This explains why it was noticed so often in the literature.

Cyber-physical systems received more attention in the literature to perform planning and scheduling related activities (category 2) compared with the two other categories. For category 1 , the share of CPS is $12 \%$ and one of the purposes of using this technology is to increase efficiency on the shopfloor as stated in Section 3. Even though the number of use cases for CPS in category 2 is less, there are evidences of creating value for PL systems through integrating CPS with other information systems such as ERP and WMS. In addition, CPS is mentioned as one of the main enabler of a smart factory concept including smart warehouse and smart material handling.

As tracking and tracing activities require constant monitoring of the moving items across production facilities, the role of wireless technologies become more obvious, as pointed out in Figure 4. The same argument is true for planning related activities in category 2. For category 1 , the role of wireless connection technologies are less mentioned by the literature despite the fact that an effective connectivity has a fundamental role in a well-established data-driven system.

IoT and IoS (Internet of Services) related technologies appeared with almost the same frequency for all three categories. Dealing with the synchronization issue between manufacturing and internal logistics is one of the main use cases mentioned for IoT/IoS. In addition, in line with cases from Section 3, constant connectivity of PL instruments facilitates optimization of the material flow and work flow analysis.

For shopfloor operational activities, AI and big data (BD) analytics are mentioned more often compared with the two other categories. As stated in Section 3, cases related to 
decision-making have been reported for $\mathrm{AI}$ and data analytics in shopfloor activities. As a result, those activities that require real-time feedback from the cyber space can benefit from AI related techniques to address the issues in an optimal manner. For planning purposes such as warehouse management, $\mathrm{AI}$ and BD have shown great potential according to the literature stated in Section 3. One of the prerequisites of resource planning is to analyze data from multiple sources. According to the findings, BD analytics has the potential to address this issue. To complete the tracking activities in category 3, literature suggests using AI alongside vision systems or sensor networks.

Cloud computing is mentioned more often for planning and scheduling related activities compared with the two other categories. Cloud computing technologies are mentioned in the literature together with other technologies such as smart devices. This is mainly to assure constant data availability. Cloud computing support activities such as condition monitoring, internal navigation, resource planning and machine-to-machine communication.

To deal with the physical movement of items across the production facilities and dealing with stationary activities such as packaging and palletization, mobile robots and industrial robots are mentioned more in category 1 . In fact, AGVs, industrial robots and drones are mentioned very few times in the two other categories.

Using smart devices in shopfloor operation has more hits in the literature as it involves physical material flow operation. In fact, the number of cases for controlling and tracking are few, with the exception of some described cases in planning related activities.

Vision systems and image processing has more appearance in shopfloor operational related activities as it can support activities such as quality control and navigation. It has even use cases for tracking items movement. Limited applications were mentioned for planning and scheduling by using smart cameras to inventory control.

Block chain technology is mentioned in the literature with a limited number mainly in conditions where several actors play a role across the supply chain. Tracking and tracing items and managing inventories are some examples.

\subsection{The Role of Data Life Cycle in Value Creation}

Each of the aforementioned technologies contribute to do one or several steps of acquiring, transferring, storing, analyzing or visualizing data [11]. Considering the data applications presented in Section 3, just collecting data from the shopfloor will not be enough to create value for the PL system. In order to create value for PL systems, it is important that the collected data from data sources, follow the data life cycle presented in Figure 5. As illustrated, the identified technologies support the value creation process by contributing to one or several steps of the presented data life cycle. 


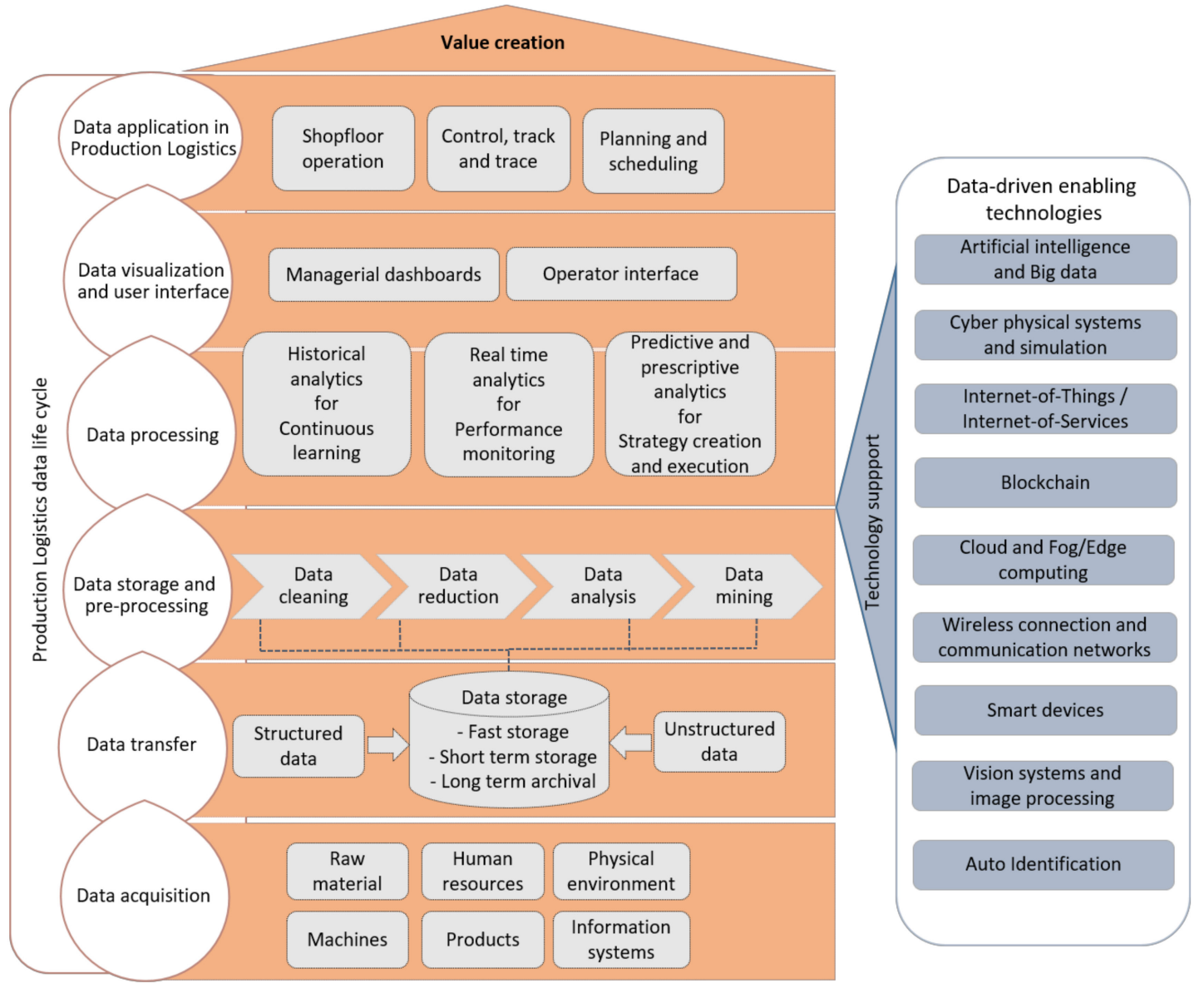

Figure 5. Data life cycle in production logistics adopted from $[5,49,116]$.

There are several data sources such as raw material, products, machines, human resources, physical environment such as buildings and existing IT systems such as enterprise systems and information systems. Any technology such as auto-id, vision systems, robots and sensor networks can be used to collect data $[65,91,118,170]$. To transfer the collected data, cellular networks and wireless connections can be used [104]. As the volume of data is significantly large, data needs to be stored for further use. Before storing the data, it is necessary to process the collected data, as there might exist redundancy, duplications and noise, and generally raw data might be of low quality. Typically, the data preprocessing includes data cleaning, data integration and data compression [49].

For data storage, there are different possibilities including conventional database technologies and new approaches such as cloud services. Cloud services have the potential to provide a flexible, cost-efficient solution [110]. The data can be stored either as structured (digits, symbols and tables) or unstructured (video, audio, etc.) [5]. In order to use the value of the data, the massive amount of data needs to be reduced in to ordered, meaningful and simplified data [179]. Real-time analytics help to monitor the performance of the system in real-time and align the operation with strategic goals and targets. Predictive and prescriptive analytics support planning, forecasting and simulation for envisioning and execution of strategies [116]. The results support production logistics activities to create value for the production process.

The processed data will be visualized through managerial dashboards or operators' interface will be used for other systems such as enterprise resource planning (ERP) or warehouse management systems (WMS). The visualized data on managerial dashboards and operator interface can support decision-making processes or work instructions [94]. 


\subsection{PL Activities Correlation Assessment for Value Creation}

As presented in Section 3, there are three categories for PL activities. In order to complete the data life cycle and create value, all these three categories have to be linked to each other by means of data transferring technologies as shown in Figure 6. Three categories of PL activities are linked with their data-driven enabling technologies. In the centre of the picture, the connectivity technologies transfer the collected or analyzed data through the PL system. Cloud data center store data and solutions such as edge computing can be used to perform near device computations. Those data that require longer storage will be stored in the cloud data centre.

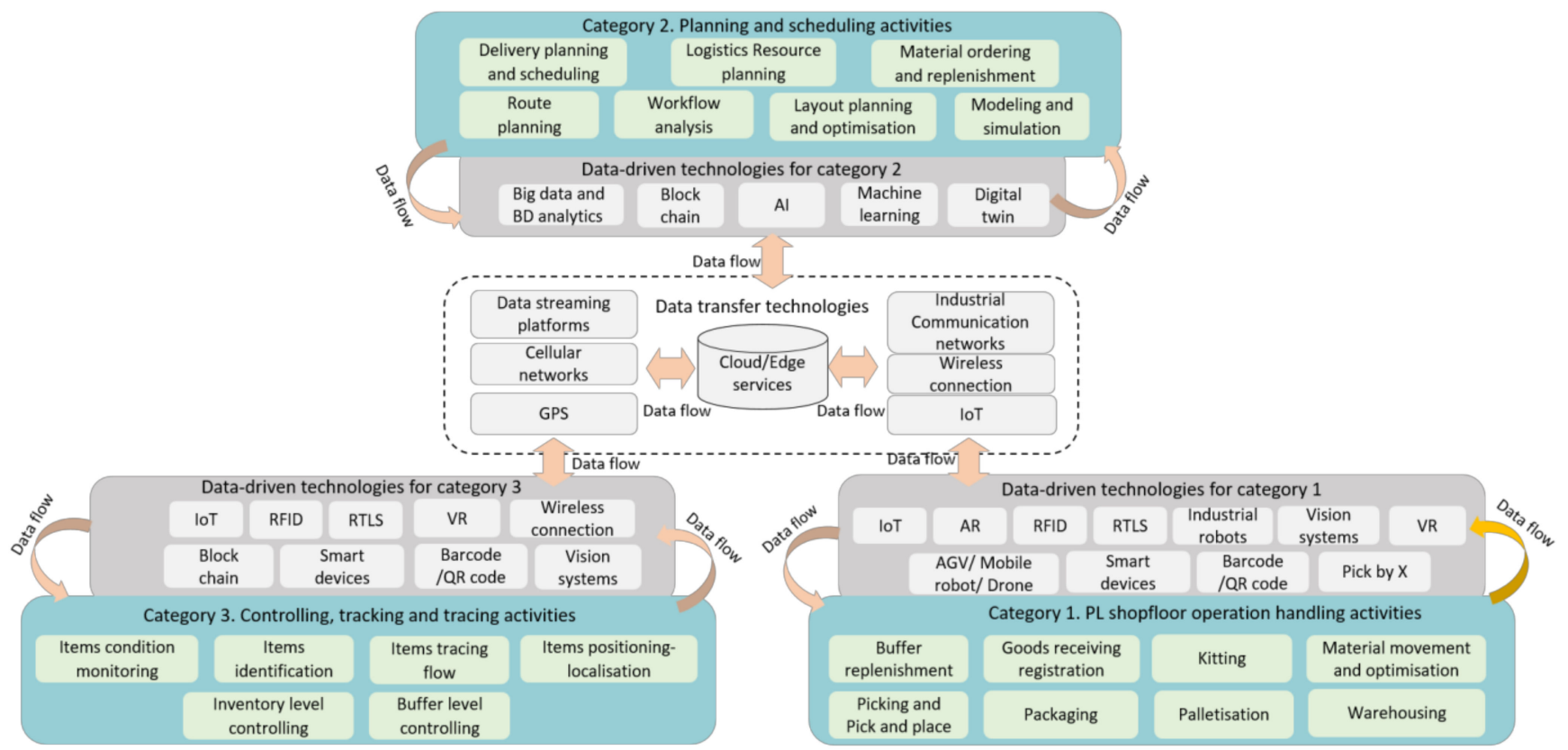

Figure 6. The correlation between three categories of PL activities and their respective data-driven technologies.

In the operational-related activities category, data acquisition and data visualization technologies support activities such as picking, packaging, warehousing, etc. Data is captured from these activities to follow the data life cycle steps and will come back to the shopfloor in the form of work instructions and decision-making support visualized by means of a human-machine interface (HMI) such as pick by vision. If the activities are automated, the machines or robots will receive instructions or decision-making support such as real-time coordinates for AGV navigation. As the operations move on, these activities need to be monitored to make sure they are in line with the operational targets. Technologies such as RFID, virtual reality (VR) and vision systems play an important role in monitoring. Tracing and tracking the operation is heavily dependent on data transferring technologies such as IoT, wireless networks and cellular networks.

The stability of networks is necessary to make sure data is produced and consumed at the right time. Otherwise, data will have less value for the operation. To have an efficient PL system, in addition to having a long-term plan and strategy, it is essential to have a dynamic planning system to be able to cope with the latest changes occurring on the shopfloor. This will not happen unless there are strong data analysis tools and techniques that can analyze historical and real-time data. Big data, block chain and AI are some examples of these technologies. Dynamic delivery planning, dynamic route planning and dynamic logistics resource planning are some examples of the activities that require real-time data. Layout planning, modeling and simulation, and workflow analysis are examples of activities that need historical information. The data produced by each of these three categories needs to be transferred through technologies such as industrial wireless networks, wireless connections, cellular networks and enterprise service bus (ESB). To store 
the data, cloud services can provide a flexible and cost-effective solution as the data will be available with no physical restrictions. The data is available to all other activities and all stakeholders can access the required data at any time.

In order to have a balanced data-driven PL system, it is imperative that each of the three PL categories receives consistent support from the enabling technologies. Data quality needs to be secured in all the data life cycle stages, from data acquisition to data visualization and user interface. It is reasonable to argue that data availability should be the main concern for a data-driven system.

As a result, all the means and technologies should have a high level of reliability, which indicates any technology introduction requires thorough consideration. The enabling technologies should be developed and implemented in a homogenous manner, aiming to create a balanced system supporting data flow across the system. Considering the importance of system reliability and data availability, partial investment in enabling technologies will not be sufficient. Consequently, regardless of the type of technology, a systematic approach towards PL development is a prerequisite to meeting data-driven manufacturing and autonomous supply chains. This result has importance for PL system owners, as they should pose clear requirements towards technology developers to deliver a reliable, robust and homogenous system. Besides, long-term targets should be favored over short-term outcomes in organizational strategies.

The number of industrial implementation for some of the technologies is few in comparison with older technologies such as RFID. For example, there is little empirical evidence from implementing technologies within data storage, data processing, and data visualization. Most of the work is in the preparatory or theoretical level.

The variety of technologies in data acquisition is relatively high compared to other data life cycle stages. High variation in data collection challenges other steps in the data life cycle as having so many data sources and data formats requires considerable effort to complete the life cycle and create value. In addition, the technologies maturity level is inhomogeneous. Technologies related to data acquisition and data transfer have a longer implementation history compared to technologies in data storage, data processing and data visualization. Companies who wish to invest on technologies should be aware of the fact that, those new technologies might suffer from immaturity. As an example, AI, Big Data analytics, block chain and machine learning are constantly evolving compare to some other technologies such as RFID and Barcode. This can cause compatibility issues as some of the older technologies might be obsolete and new technologies might have integration problems with legacy systems. As a result, having a long-term perspective in technology assessment is inevitable.

\section{Conclusions and Future Research}

In this paper, data-driven PL enabling technologies and their use cases were presented based on a SLR through reviewing 142 journal articles, and their association with PL activities were discussed. Production logistics activities were divided into three main categories including shopfloor activities, planning and scheduling activities, and controlling, tracking and tracing activities. The identified technologies were grouped in to 10 types and for each PL activity category, the share of technologies assessed accordingly. The result helps researchers and business owners to have a more precise picture on how technologies are mentioned in the literature for PL activities from a system perspective. This helps to build a ground to transit towards a data-driven state by knowing the applications and use cases described in the literature for the technologies.

In addition, it is discussed how the identified technologies can contribute to value creation from a holistic perspective. The production logistics data life cycle is presented and different steps within the life cycle is described. As discussed in Section 4, performing data collection, data transfer, data storage, data analysis and data visualization should happen as a chain in order to create business value for the production logistics system. Simply collecting or storing data does not lead to value creation. 
It is argued that employing a data-driven approach in PL requires balanced longterm attention to technological enablers as the maturity level of existing technologies are inhomogeneous. Some of the technologies might become obsolete over time and some others are evolving and will have wider applications such as data analytics. This needs to be considered in technology assessment processes. In line with Figure 6, there are several technologies that are associated with PL activities categories. Even though data transfer technologies have no direct value-creation for PL, their stability is of great importance to have a sustainable data-driven system.

This research has contributed to both academia and industry in the following ways. Several activities within production logistics are presented with respect to those technologies that help to adopt a data-driven approach for manufacturing and autonomous supply chains. Categorizing the PL activities is also helping the researchers to have a more comprehensive perspective regarding technology assessment. This research has provided the opportunity to have a wider look onto the digitalization journey for companies by presenting the "big picture" while identifying technologies and their application in data-driven PL. From a value creation perspective, the importance of having a long-term perspective and balanced development are discussed. This will help decision makers for any future investments.

Following points are suggested for future research:

- This study did not investigate the impact of each technology on PL system performance. Thus, for future research, it is suggested to study and measure how system performance can be affected after the PL system is transited towards a data-driven state. The outcome of this paper is beneficial to suggest technologies enabling the transition towards a data-driven state. In particular and considering Figure 6, those technologies related to PL planning and scheduling have a shorter history of implementation compared to the two other categories. As a result, it is hard to judge the efficiency of the technologies in the planning and scheduling category within different industrial situations. It is therefore interesting for future research to examine the efficiency and implementation feasibility of technologies related to planning and scheduling from a production logistics perspective.

- Even though this study has discussed the supporting role of identified technologies to complete the data-life cycle and value creation, still, the corresponding role of each technology in each phase of data-life cycle needs further investigation. By performing such a study in future, it will be clear which areas need more attention from a technology developers' perspective.

- This study carried out a quantitative assessment on technology share for PL activity categories. Thus, it will be interesting to investigate which of these use cases has been already proven and are feasible for implementation and which technologies require further approval. This can be significant to recognize the challenges ahead of a digitalization transition.

Author Contributions: Conceptualization, M.W., J.B.H. and M.Z.; methodology, M.Z., M.W., J.B.H.; validation, M.W., J.B.H. and M.Z.; formal analysis, M.Z., M.W., J.B.H.; data curation, M.Z.; writingoriginal draft preparation, M.Z.; writing—review and editing, M.W., J.B.H.; visualization, M.Z.; supervision, M.W., J.B.H.; funding acquisition, M.W., J.B.H. All authors have read and agreed to the published version of the manuscript.

Funding: This research was funded by Vinnova and Produktion2030 for the project DigiLog-digital and physical testbed for logistic operations in production, reference number 2017-04778.

Institutional Review Board Statement: Not applicable.

Informed Consent Statement: Not applicable.

Data Availability Statement: The data presented in this study are already presented in this manuscript. 
Acknowledgments: The authors would like to acknowledge the financial support of Vinnova and Produktion2030 for the project DigiLog—digital and physical testbed for logistic operations in production.

Conflicts of Interest: The authors declare no conflict of interest. The funders had no role in the design of the study; in the collection, analyses, or interpretation of data; in the writing of the manuscript, or in the decision to publish the results.

\section{References}

1. Cámara, S.B.; Fuentes, J.M.; Marín, J.M.M. Cloud computing, Web 2.0, and operational performance. Mediat. Role Supply Chain Integr. 2015, 26, 3.

2. Novais, L.; Marín, J.M.M.; Moyano-Fuentes, J. Lean Production implementation, Cloud-Supported Logistics and Supply Chain Integration: Interrelationships and effects on business performance. Int. J. Logist. Manag. 2020, 31, 629-663. [CrossRef]

3. Barreto, L.; Amaral, A.; Pereira, T. Industry 4.0 implications in logistics: An overview. Procedia Manuf. 2017, 13, 1245-1252. [CrossRef]

4. Treiblmaier, H.; Mirkovski, K.; Lowry, P.B.; Zacharia, Z.G. The physical internet as a new supply chain paradigm: A systematic literature review and a comprehensive framework. Int. J. Logist. Manag. 2020, 31, 239-287. [CrossRef]

5. Tao, F.; Qi, Q.; Liu, A.; Kusiak, A. Data-driven smart manufacturing. J. Manuf. Syst. 2018, 48, 157-169. [CrossRef]

6. Nitsche, B. Unravelling the Complexity of Supply Chain Volatility Management. Logistics 2018, 2, 14. [CrossRef]

7. Horňáková, N.; Jurík, L.; Chovanová, H.H.; Cagáňová, D.; Babčanová, D. AHP method application in selection of appropriate material handling equipment in selected industrial enterprise. Wirel. Netw. 2019, 1-9. [CrossRef]

8. Davich, T. Material Handling Solutions: A Look into Automated Robotics. Resource Document. 2010. Available online: https:/ / tctest.wiscweb.wisc.edu/wp-content/uploads/sites/142/2017/04/Davich2010.pdf (accessed on 6 April 2021).

9. $\quad$ Kang, H.S.; Lee, J.Y.; Choi, S.; Kim, H.; Park, J.H.; Son, J.Y.; Kim, B.H.; Noh, S.D. Smart manufacturing: Past research, present findings, and future directions. Int. J. Precis. Eng. Manuf. Technol. 2016, 3, 111-128. [CrossRef]

10. Winkelhaus, S.; Grosse, E.H. Logistics 4.0: A systematic review towards a new logistics system. Int. J. Prod. Res. 2020, 58, 18-43. [CrossRef]

11. Klingenberg, C.O.; Borges, M.A.V.; Antunes, J.A.V., Jr. Industry 4.0 as a data-driven paradigm: A systematic literature review on technologies. J. Manuf. Technol. Manag. 2019. Ahead of Publication. [CrossRef]

12. Cao, W.; Jiang, P.; Lu, P.; Liu, B. Real-time data-driven monitoring in job-shop floor based on radio frequency identification. Int. J. Adv. Manuf. Technol. 2017, 92, 2120-2357. [CrossRef]

13. Wan, J.; Tang, S.; Hua, Q.; Li, D.; Liu, C.; Lloret, J. Context-Aware Cloud Robotics for Material Handling in Cognitive Industrial Internet of Things. IEEE Internet Things J. 2017, 5, 2272-2281. [CrossRef]

14. Lee, C.; Lv, Y.; Ng, K.; Ho, W.; Choy, K. Design and application of Internet of things-based warehouse management system for smart logistics. Int. J. Prod. Res. 2018, 56, 2753-2768. [CrossRef]

15. Ghobakhloo, M. Determinants of information and digital technology implementation for smart manufacturing. Int. J. Prod. Res. 2020, 58, 2384-2405. [CrossRef]

16. Alcácer, V.; Cruz-Machado, V. Scanning the Industry 4.0: A Literature Review on Technologies for Manufacturing Systems. Eng. Sci. Technol. Int. J. 2019, 22, 899-919. [CrossRef]

17. Lagorio, A.; Zenezini, G.; Mangano, G.; Pinto, R. A systematic literature review of innovative technologies adopted in logistics management in logistics management. Int. J. Logist. Res. Appl. 2020. [CrossRef]

18. Martinez, S.; Astrid, J. Evaluation of the Feasibility of Implementing Industry 4.0 Technologies in the Intralogistic Processes of the Logistics Operators of the Department of the Atlantic, a Look Towards the Continuous Improvement of Organizational Efficiency. In Data Analysis and Optimization for Engineering and Computing Problems; Vasant, P., Litvinchev, I., Marmolejo-Saucedo, J.A., Rodriguez-Aguilar, R., Martinez-Rios, F., Eds.; Springer International Publishing: Berlin/Heidelberg, Germany, 2020.

19. Mittal, S.; Khan, M.A.; Romero, D.; Wuest, T. Smart manufacturing: Characteristics, technologies and enabling factors. Proc. Inst Mech. Eng. Part B J. Eng. Manuf. 2019, 233, 1342-1361. [CrossRef]

20. Oztemel, E.; Gursev, S. Literature review of Industry 4.0 and related technologies. J. Intell. Manuf. 2020, 31, 127-182. [CrossRef]

21. Thoben, K.D.; Wiesner, S.A.; Wuest, T. 'Industrie 4.0' and smart manufacturing-a review of research issues and application examples. Int. J. Autom. Technol. 2017, 11, 4-16. [CrossRef]

22. Chien, C.-F.; Hong, T.-Y.; Guo, H.-Z. An empirical study for smart production for TFT-LCD to empower Industry 3.5. J. Chin. Inst. Eng. 2017, 40, 552-561. [CrossRef]

23. Lin, K.C.; Shyu, J.Z.; Ding, K. A Cross-Strait Comparison of Innovation Policy under Industry 4.0 and Sustainability Development Transition. Sustainability 2017, 9, 786. [CrossRef]

24. Chiarello, F.; Trivelli, L.; Bonaccorsi, A.; Fantoni, G. Extracting and mapping industry 4.0 technologies using wikipedia. Comput. Ind. 2018, 100, 244-257. [CrossRef]

25. Chavez, R.; Yu, W.; Jacobs, M.A.; Feng, M. Data-driven supply chains, manufacturing capability and customer satisfaction. Prod. Plan. Control 2017, 28, 906-918. [CrossRef]

26. Rossit, D.A.; Tohmé, F.; Frutos, M. A data-driven scheduling approach to smart manufacturing. J. Ind. Inf. Integr. 2019, 15, 69-79. [CrossRef] 
27. Woo, J.; Shin, S.-J.; Seo, W.; Meilanitasari, P. Developing a big data analytics platform for manufacturing systems: Architecture, method, and implementation. Int. J. Adv. Manuf. Technol. 2018, 99, 2193-2217. [CrossRef]

28. Frank, A.G.; Dalenogare, L.S.; Ayala, N.F. Industry 4.0 technologies: Implementation patterns in manufacturing companies. Int. J. Prod. Econ. 2019, 210, 15-26. [CrossRef]

29. Ghobakhloo, M.; Ching, N.T. Adoption of digital technologies of smart manufacturing in SMEs. J. Ind. Inf. Integr. 2019, 16, 100107. [CrossRef]

30. Strandhagen, J.W.; Alfnes, E.; Vallandingham, L.R. The fit of Industry 4.0 applications in manufacturing logistics: A multiple case study. Adv. Manuf. 2017, 5, 344-358. [CrossRef]

31. Nagy, G.; Illés, B.; Bányai, Á. Impact of Industry 4.0 on production logistics. IOP Conf. Series: Mater. Sci. Eng. 2018, 448,012013 [CrossRef]

32. Collins Dictionary. 2020. Available online: https://www.collinsdictionary.com/dictionary/english/technology\#: \{\}:text= Technologyreferstomethods\%2Csystems (accessed on 1 June 2020).

33. Thorpe, R.; Holt, R.; Macpherson, A.; Pittaway, L. Using Knowledge within Small and Medium-sized Firms: A Systematic Review of the Evidence. Int. J. Manag. Rev. 2005, 4, 257-281. [CrossRef]

34. Tranfield, D.; Denyer, D.; Smart, P. Towards a Methodology for Developing Evidence-Informed Management Knowledge by Means of Systematic Review. Br. J. Manag. 2003, 14, 207-222. [CrossRef]

35. Hofmann, E.; Rüsch, M. Industry 4.0 and the current status as well as future prospects on logistics. Comput. Ind. 2017, 89, 23-34 [CrossRef]

36. Eklund, J.; Palm, K.; Bergman, A.; Rosenblad, C.; Aronsson, G. Work environment of the future-Trends, digitalization and employment forms: Three systematic reviews. Available online: https://sawee.se/publications/work-environment-of-thefuture-trends-digitalization-and-employment-forms/ (accessed on 6 April 2021).

37. Park, K.T.; Nam, Y.W.; Lee, H.S.; Im, S.J.; Noh, S.D.; Son, J.Y.; Kim, H. Design and implementation of a digital twin application for a connected micro smart factory. Int. J. Comput. Integr. Manuf. 2019, 32, 596-614. [CrossRef]

38. Ren, S.; Zhao, X.; Huang, B.; Wang, Z.; Song, X. A framework for shopfloor material delivery based on real-time manufacturing big data. J. Ambient. Intell. Humaniz. Comput. 2018, 10, 1093-1108. [CrossRef]

39. Sanders, A.; Elangeswaran, C.; Wulfsberg, J. Industry 4.0 implies lean manufacturing: Research activities in industry 4.0 function as enablers for lean manufacturing. J. Ind. Eng. Manag. 2016, 9, 811-833. [CrossRef]

40. Wang, S.; Zhang, C.; Liu, C.; Li, D.; Tang, H. Cloud-assisted interaction and negotiation of industrial robots for the smart factory. Comput. Electr. Eng. 2017, 63, 66-78. [CrossRef]

41. Zhang, Y.; Qian, C.; Lv, J.; Liu, Y. Agent and Cyber-Physical System Based Self-Organizing and Self-Adaptive Intelligent Shopfloor. IEEE Trans. Ind. Inform. 2017, 13, 737-747. [CrossRef]

42. Zhang, Y.; Wang, W.; Wu, N.; Qian, C. IoT-Enabled Real-Time Production Performance Analysis and Exception Diagnosis Model. IEEE Trans. Autom. Sci. Eng. 2016, 13, 1318-1332. [CrossRef]

43. Zheng, M.; Ming, X. Construction of cyber-physical system-integrated smart manufacturing workshops: A case study in automobile industry. Adv. Mech. Eng. 2017, 9, 1-17. [CrossRef]

44. Zhong, R.Y.; Xu, C.; Chen, C.; Huang, G.Q. Big Data Analytics for Physical Internet-based intelligent manufacturing shop floors. Int. J. Prod. Res. 2017, 55, 2610-2621. [CrossRef]

45. Zhuang, C.; Liu, J.; Xiong, H. Digital twin-based smart production management and control framework for the complex product assembly shop-floor. Int. J. Adv. Manuf. Technol. 2018, 96, 1149-1163. [CrossRef]

46. Chen, W. Intelligent manufacturing production line data monitoring system for industrial internet of things. Comput. Commun. 2020, 151, 31-41. [CrossRef]

47. Qu, T.; Thürer, M.; Wang, J.; Wang, Z.; Fu, H.; Li, C.; Huang, G.Q. System dynamics analysis for an Internet-of-Things-enabled production logistics system. Int. J. Prod. Res. 2017, 55, 2622-2649. [CrossRef]

48. Ding, K.; Chan, F.T.; Zhang, X.; Zhou, G.; Zhang, F. Defining a Digital Twin-based Cyber-Physical Production System for autonomous manufacturing in smart shop floors. Int. J. Prod. Res. 2019, 57, 6315-6334. [CrossRef]

49. Dai, H.-N.; Wang, H.; Xu, G.; Wan, J.; Imran, M. Big data analytics for manufacturing internet of things: Opportunities, challenges and enabling technologies. Enterp. Inf. Syst. 2020, 14, 1279-1303. [CrossRef]

50. Chung, K.; Yoo, H.; Choe, D.; Jung, H. Blockchain Network Based Topic Mining Process for Cognitive Manufacturing. Wirel. Pers. Commun. 2019, 105, 583-597. [CrossRef]

51. Chang, H. Performance evaluation framework design for smart sensor business. J. Supercomput. 2017, 74, 4481-4496. [CrossRef]

52. Bortolini, M.; Ferrari, E.; Gamberi, M.; Pilati, F.; Faccio, M. Assembly system design in the Industry 4.0 era: A general framework. IFAC-PapersOnLine 2017, 50, 5700-5705. [CrossRef]

53. Trappey, A.J.C.; Trappey, C.V.; Fan, C.-Y.; Hsu, A.P.T.; Li, X.-K.; Lee, I.J.Y. IoT patent roadmap for smart logistic service provision in the context of Industry 4.0. J. Chin. Inst. Eng. 2017, 40, 593-602. [CrossRef]

54. Sicari, S.; Rizzardi, A.; Coen-Porisini, A. How to evaluate an Internet of Things system: Models, case studies, and real developments. Software: Pract. Exp. 2019, 49, 1663-1685. [CrossRef]

55. Tao, F.; Qi, Q. New IT Driven Service-Oriented Smart Manufacturing: Framework and Characteristics. IEEE Trans. Syst. Man Cybern. Syst. 2017, 49, 81-91. [CrossRef] 
56. Lyu, Z.; Lin, P.; Guo, D.; Huang, G.Q. Towards Zero-Warehousing Smart Manufacturing from Zero-Inventory Just-In-Time production. Robot. Comput. Manuf. 2020, 64, 101932. [CrossRef]

57. De Sousa Jabbour, A.B.L.; Jabbour, C.J.C.; Godinho-Filho, M.; Roubaud, D. Industry 4.0 and the circular economy: A proposed research agenda and original roadmap for sustainable operations. Ann. Oper. Res. 2018, 270, 273-286. [CrossRef]

58. Mehmood, Y.; Marwat, S.N.K.; Kuladinithi, K.; Förster, A.; Zaki, Y.; Görg, C.; Timm-Giel, A. M2M Potentials in logistics and transportation industry. Logist. Res. 2016, 9, 15. [CrossRef]

59. Kolberg, D.; Knobloch, J.; Zühlke, D. Towards a lean automation interface for workstations. Int. J. Prod. Res. 2017, 55, 2845-2856. [CrossRef]

60. Li, X.; Li, D.; Wan, J.; Vasilakos, A.V.; Lai, C.-F.; Wang, S. A review of industrial wireless networks in the context of Industry 4.0. Wirel. Netw. 2017, 23, 23-41. [CrossRef]

61. Dotoli, M.; Fay, A.; Miśkowicz, M.; Seatzu, C. An overview of current technologies and emerging trends in factory automation. Int. J. Prod. Res. 2019, 57, 5047-5067. [CrossRef]

62. Egger, J.; Masood, T. Augmented reality in support of intelligent manufacturing-A systematic literature review. Comput. Ind. Eng. 2020, 140, 106195. [CrossRef]

63. Al-Jaroodi, J.; Mohamed, N.; Jawhar, I. A service-oriented middleware framework for manufacturing industry 4.0. ACM SIGBED Rev. 2018, 15, 29-36. [CrossRef]

64. Kovalenko, I.; Saez, M.; Barton, K.; Tilbury, D. SMART: A System-Level Manufacturing and Automation Research Testbed. Smart Sustain. Manuf. Syst. 2017, 1, 20170006. [CrossRef]

65. Kembro, J.H.; Danielsson, V.; Smajli, G. Network video technology: Exploring an innovative approach to improving warehouse operations. Int. J. Phys. Distrib. Logist. Manag. 2017, 47, 623-645. [CrossRef]

66. Tu, M.; Lim, M.K.; Yang, M.F. IoT-based production logistics and supply chain system-Part 2 IoT-based cyber-physical system: A framework and evaluation. Ind. Manag. Data Syst. 2018, 118, 96-125. [CrossRef]

67. Mahmud, B. Internet of things (IoT) for manufacturing logistics on SAP ERP applications. J. Telecommun. Electron. Comput. Eng. 2017, 9, 43-47.

68. Kant, K.; Pal, A. Internet of Perishable Logistics. IEEE Internet Comput. 2017, 21, 22-31. [CrossRef]

69. Meng, Z.; Wu, Z.; Gray, J. RFID-Based Object-Centric Data Management Framework for Smart Manufacturing Applications. IEEE Internet Things J. 2019, 6, 2706-2716. [CrossRef]

70. Zhang, Y.; Xu, X.; Liu, A.; Lu, Q.; Xu, L.; Tao, F. Blockchain-Based Trust Mechanism for IoT-Based Smart Manufacturing System. IEEE Trans. Comput. Soc. Syst. 2019, 6, 1386-1394. [CrossRef]

71. Hao, Y.; Helo, P. The role of wearable devices in meeting the needs of cloud manufacturing: A case study. Robot. Comput. Manuf. 2017, 45, 168-179. [CrossRef]

72. Trentesaux, D.; Borangiu, T.; Thomas, A. Emerging ICT concepts for smart, safe and sustainable industrial systems. Comput. Ind. 2016, 81, 1-10. [CrossRef]

73. Costanzo, M.; De Maria, G.; Lettera, G.; Natale, C.; Pirozzi, S. Motion Planning and Reactive Control Algorithms for Object Manipulation in Uncertain Conditions. Robotics 2018, 7, 76. [CrossRef]

74. Culler, D.; Long, J. A Prototype Smart Materials Warehouse Application Implemented Using Custom Mobile Robots and Open Source Vision Technology Developed Using EmguCV. Procedia Manuf. 2016, 5, 1092-1106. [CrossRef]

75. Liao, Y.; Panetto, H.; Stadzisz, P.C.; Simão, J.M. A notification-oriented solution for data-intensive enterprise information systems-A cloud manufacturing case. Enterp. Inf. Syst. 2018, 12, 942-959. [CrossRef]

76. Stark, R.; Fresemann, C.; Lindow, K. Development and operation of Digital Twins for technical systems and services. CIRP Ann. 2019, 68, 129-132. [CrossRef]

77. Mueller, E.; Chen, X.-L.; Riedel, R. Challenges and Requirements for the Application of Industry 4.0: A Special Insight with the Usage of Cyber-Physical System. Chin. J. Mech. Eng. 2017, 30, 1050-1057. [CrossRef]

78. Wang, X.; Yew, A.; Ong, S.; Nee, A. Enhancing smart shop floor management with ubiquitous augmented reality. Int. J. Prod. Res. 2019, 58, 2352-2367. [CrossRef]

79. Masood, T.; Egger, J. Augmented reality in support of Industry 4.0-Implementation challenges and success factors. Robot. Comput. Manuf. 2019, 58, 181-195. [CrossRef]

80. Leung, K.; Choy, K.; Siu, P.K.; Ho, G.; Lam, H.; Lee, C.K. A B2C e-commerce intelligent system for re-engineering the e-order fulfilment process. Expert Syst. Appl. 2018, 91, 386-401. [CrossRef]

81. Wahrmann, D.; Hildebrandt, A.-C.; Schuetz, C.; Wittmann, R.; Rixen, D. An Autonomous and Flexible Robotic Framework for Logistics Applications. J. Intell. Robot. Syst. 2017, 93, 419-431. [CrossRef]

82. Schuhmacher, J.; Baumung, W.; Hummel, V. An Intelligent Bin System for Decentrally Controlled Intralogistic Systems in Context of Industrie 4.0. Procedia Manuf. 2017, 9, 135-142. [CrossRef]

83. Huang, B.; Wang, W.; Ren, S.; Zhong, R.Y.; Jiang, J. A proactive task dispatching method based on future bottleneck prediction for the smart factory. Int. J. Comput. Integr. Manuf. 2019, 32, 278-293. [CrossRef]

84. Hohmann, C.; Posselt, T. Design challenges for CPS-based service systems in industrial production and logistics. Int. J. Comput. Integr. Manuf. 2018, 32, 329-339. [CrossRef]

85. Leng, J.; Zhang, H.; Yan, D.; Liu, Q.; Chen, X.; Zhang, D. Digital twin-driven manufacturing cyber-physical system for parallel controlling of smart workshop. J. Ambient. Intell. Humaniz. Comput. 2019, 10, 1155-1166. [CrossRef] 
86. Liu, B.; Zhang, Y.; Zhang, G.; Zheng, P. Edge-cloud orchestration driven industrial smart product-service systems solution design based on CPS and IIoT. Adv. Eng. Inform. 2019, 42, 100984. [CrossRef]

87. Li, G.; Zeng, B.; Liao, W.; Li, X.; Gao, L. A new AGV scheduling algorithm based on harmony search for material transfer in a real-world manufacturing system. Adv. Mech. Eng. 2018, 10. [CrossRef]

88. Küsters, D.; Praß, N.; Gloy, Y.-S. Textile Learning Factory 4.0-Preparing Germany's Textile Industry for the Digital Future. Procedia Manuf. 2017, 9, 214-221. [CrossRef]

89. Lu, S.; Xu, C.; Zhong, R.Y.; Wang, L. A RFID-enabled positioning system in automated guided vehicle for smart factories. J. Manuf. Syst. 2017, 44, 179-190. [CrossRef]

90. Madsen, O.; Møller, C. The AAU Smart Production Laboratory for Teaching and Research in Emerging Digital Manufacturing Technologies. Procedia Manuf. 2017, 9, 106-112. [CrossRef]

91. Wang, S.; Wan, J.; Li, D.; Zhang, C. Implementing Smart Factory of Industrie 4.0: An Outlook. Int. J. Distrib. Sens. Netw. 2016, 12. [CrossRef]

92. Wan, J.; Chen, B.; Imran, M.; Tao, F.; Li, D.; Liu, C.; Ahmad, S. Toward dynamic resources management for IoT-based manufacturing. IEEE Commun. Mag. 2018, 56, 52-59. [CrossRef]

93. Tang, D.; Zheng, K.; Zhang, H.; Zhang, Z.; Sang, Z.; Zhang, T.; Espinosa-Oviedo, J.-A.; Vargas-Solar, G. Using autonomous intelligence to build a smart shop floor. Int. J. Adv. Manuf. Technol. 2017, 94, 1597-1606. [CrossRef]

94. Rojko, A. Industry 4.0 Concept: Background and Overview. Int. J. Interact. Mob. Technol. 2017, 11, 77-90. [CrossRef]

95. Yan, H.; Hua, Q.; Wang, Y.; Wei, W.; Imran, M. Cloud robotics in Smart Manufacturing Environments: Challenges and countermeasures. Comput. Electr. Eng. 2017, 63, 56-65. [CrossRef]

96. Zhang, Y.; Zhu, Z.; Lv, J. CPS-Based Smart Control Model for Shopfloor Material Handling. IEEE Trans. Ind. Inform. 2018, 14, 1764-1775. [CrossRef]

97. Da Silva, V.L.; Kovaleski, J.L.; Pagani, R.N. Technology transfer in the supply chain oriented to industry 4.0: A literature review. Technol. Anal. Strat. Manag. 2018, 31, 546-562. [CrossRef]

98. Chen, G.; Wang, P.; Feng, B.; Li, Y.; Liu, D. The framework design of smart factory in discrete manufacturing industry based on cyber-physical system. Int. J. Comput. Integr. Manuf. 2019, 33, 79-101. [CrossRef]

99. Cadavid, J.P.U.; Lamouri, S.; Grabot, B.; Pellerin, R.; Fortin, A. Machine learning applied in production planning and control: A state-of-the-art in the era of industry 4.0. J. Intell. Manuf. 2020, 31, 1531-1558. [CrossRef]

100. Suginouchi, S.; Kokuryo, D.; Kaihara, T. Value Co-creative Manufacturing System for Mass Customization: Concept of Smart Factory and Operation Method Using Autonomous Negotiation Mechanism. Procedia CIRP 2017, 63, 727-732. [CrossRef]

101. Gröhn, L.; Metsälä, S.; Nyholm, M.; Saikko, L.; Väänänen, E.; Gulzar, K.; Vyatkin, V. Manufacturing System Upgrade with Wireless and Distributed Automation. Procedia Manuf. 2017, 11, 1012-1018. [CrossRef]

102. Szafir, D.; Mutlu, B.; Fong, T. Designing planning and control interfaces to support user collaboration with flying robots. Int. J. Robot. Res. 2017, 36, 514-542. [CrossRef]

103. Semwal, T.; Jha, S.S.; Nair, S.B. On Ordering Multi-Robot Task Executions within a Cyber Physical System. ACM Trans. Auton. Adapt. Syst. 2018, 12, 1-27. [CrossRef]

104. Cheng, J.; Chen, W.; Tao, F.; Lin, C.-L. Industrial IoT in 5G environment towards smart manufacturing. J. Ind. Inf. Integr. 2018, 10, 10-19. [CrossRef]

105. Damiani, L.; Demartini, M.; Guizzi, G.; Revetria, R.; Tonelli, F. Augmented and virtual reality applications in industrial systems: A qualitative review towards the industry 4.0 era. IFAC PapersOnLine 2018, 51, 624-630. [CrossRef]

106. Avventuroso, G.; Silvestri, M.; Pedrazzoli, P. A Networked Production System to Implement Virtual Enterprise and Product Lifecycle Information Loops. IFAC-PapersOnLine 2017, 50, 7964-7969. [CrossRef]

107. Zhong, X.; Xu, R.Y.; Wang, L. IoT-enabled Smart Factory Visibility and Traceability Using Laser-scanners. Procedia Manuf. 2017, 10, 1-14. [CrossRef]

108. Závadská, Z.; Závadský, J. Quality managers and their future technological expectations related to Industry 4.0. Total. Qual. Manag. Bus. Excel. 2018, 31, 717-741. [CrossRef]

109. Guo, D.; Zhong, R.Y.; Lin, P.; Lyu, Z.; Rong, Y.; Huang, G.Q. Digital twin-enabled Graduation Intelligent Manufacturing System for fixed-position assembly islands. Robot. Comput. Manuf. 2020, 63, 101917. [CrossRef]

110. Zhang, K.; Wan, M.; Qu, T.; Jiang, H.; Li, P.; Chen, Z.; Xiang, J.; He, X.; Li, C.; Huang, G.Q. Production service system enabled by cloud-based smart resource hierarchy for a highly dynamic synchronized production process. Adv. Eng. Inform. 2019, $42,100995$. [CrossRef]

111. Zheng, P.; Lin, Y.; Chen, C.-H.; Xu, X. Smart, connected open architecture product: An IT-driven co-creation paradigm with lifecycle personalization concerns. Int. J. Prod. Res. 2018, 57, 2571-2584. [CrossRef]

112. Zhang, K.; Qu, T.; Zhou, D.; Thürer, M.; Liu, Y.; Nie, D.; Li, C.; Huang, G.Q. IoT-enabled dynamic lean control mechanism for typical production systems. J. Ambient Intell. Humaniz. Comput. 2019, 10, 1009-1023. [CrossRef]

113. Yang, H.; Kumara, S.; Bukkapatnam, S.T.; Tsung, F. The internet of things for smart manufacturing: A review. IISE Trans. 2019, 51, 1190-1216. [CrossRef]

114. Priya, B.; Malhotra, J. 5GAuNetS: An autonomous 5G network selection framework for Industry 4.0. Soft Comput. 2020, 24, 9507-9523. [CrossRef] 
115. Mahroof, K. A human-centric perspective exploring the readiness towards smart warehousing: The case of a large retail distribution warehouse. Int. J. Inf. Manag. 2019, 45, 176-190. [CrossRef]

116. Hopkins, J.; Hawking, P. Big Data Analytics and IoT in logistics: A case study. Int. J. Logist. Manag. 2018, 29, 575-591. [CrossRef]

117. Li, J.-Q.; Yu, F.R.; Deng, G.; Luo, C.; Ming, Z.; Yan, Q. Industrial Internet: A Survey on the Enabling Technologies, Applications, and Challenges. IEEE Commun. Surv. Tutorials 2017, 19, 1504-1526. [CrossRef]

118. Feng, J.; Li, F.; Xu, C.; Zhong, R.Y. Data-Driven Analysis for RFID-Enabled Smart Factory: A Case Study. IEEE Trans. Syst. Man, Cybern. Syst. 2018, 50, 81-88. [CrossRef]

119. Ding, K.; Jiang, P. RFID-based production data analysis in an IoT-enabled smart job-shop. IEEE/CAA J. Autom. Sin. 2018, 5, 128-138. [CrossRef]

120. Zhou, W.; Piramuthu, S.; Chu, F.; Chu, C. RFID-enabled flexible warehousing. Decis. Support Syst. 2017, 98, 99-112. [CrossRef]

121. Kim, J.-Y.; Park, D.-J. Internet-of-Things Based Approach for Warehouse Management System. Int. J. Multimedia Ubiquitous Eng. 2016, 11, 159-166. [CrossRef]

122. Franceschini, F.; Galetto, M.; Maisano, L.; Mastrogiacomo, D. Towards the use 20 of augmented reality techniques for assisted acceptance sampling. Proc. Inst. Mech. Eng. Part B J. Eng. Manuf. 2016, 230, 1870-1884. [CrossRef]

123. Sarupuri, B.; Lee, G.A.; Billinghurst, M. Using augmented reality to assist forklift operation. In Proceedings of the 28th Australian Conference on Computer-Human Interaction-OzCHI '16, Launceston, Tasmania, 29 November-2 December 2016; pp. 16-24.

124. Mättig, B.; Lorimer, I.; Kirks, T.; Jost, J. Analysis of the application of Augmented Reality in the packaging process considering specific requirements on the visualization of information as well as the ergonomic integration of humans into the process. Logist. J. Proc. 2016, 2016.

125. Gregor, M.; Medvecky, S.; Grznar, P.; Gregor, T. Smart Industry Requires Fast Response from Research to Innovation. Commun. Sci. Lett. Univ. Zilina 2017, 19, 68-73.

126. Mueller, R.; Vette, M.; Hoerauf, L.; Speicher, C.; Burkhard, D. Lean information and communication tool to connect shop and top floor in small and medium-sized enterprises. In Proceedings of the 27th International Conference on Flexible Automation and Intelligent Manufacturing, Modena, Italy, 27-30 June 2017; Volume 11, pp. 1043-1052.

127. Lee, J.; Davari, H.; Singh, J.; Pandhare, V. Industrial Artificial Intelligence for industry 4.0-based manufacturing systems. Manuf. Lett. 2018, 18, 20-23. [CrossRef]

128. Ramakrishnan, R.; Gaur, L.; Singh, G. Feasibility and Efficacy of BLE Beacon IoT Devices in Inventory Management at the Shop Floor. Int. J. Electr. Comput. Eng. (IJECE) 2016, 6, 2362. [CrossRef]

129. Zhang, J.; Ding, G.; Zou, Y.; Qin, S.; Fu, J. Review of job shop scheduling research and its new perspectives under Industry 4.0. J. Intell. Manuf. 2019, 30, 1809-1830. [CrossRef]

130. Tao, F.; Zhang, H.; Liu, A.; Nee, A.Y.C. Digital Twin in Industry: State-of-the-Art. IEEE Trans. Ind. Inform. 2019, 15, $2405-2415$. [CrossRef]

131. Qu, T.; Lei, S.P.; Wang, Z.Z.; Nie, D.X.; Chen, X.; Huang, G.Q. IoT-based real-time production logistics synchronization system under smart cloud manufacturing. Int. J. Adv. Manuf. Technol. 2016, 84, 147-164. [CrossRef]

132. Zhang, Y.; Liu, S.; Liu, Y.; Li, R. Smart box-enabled product-service system for cloud logistics. Int. J. Prod. Res. 2016, 54, 6693-6706. [CrossRef]

133. Zhang, Y.; Wang, W.; Du, W.; Qian, C.; Yang, H. Coloured Petri net-based active sensing system of real-time and multi-source manufacturing information for smart factory. Int. J. Adv. Manuf. Technol. 2017, 94, 3427-3439. [CrossRef]

134. Qu, Y.J.; Ming, X.G.; Liu, Z.W.; Zhang, X.Y.; Hou, Z.T. Smart manufacturing systems: State of the art and future trends. Int. J. Adv. Manuf. Technol. 2019, 103, 3751-3768. [CrossRef]

135. Wilkesmann, M.; Wilkesmann, U. Industry 4.0-Organizing routines or innovations? VINE J. Inf. Knowl. Manag. Syst. 2018, 48, 238-254. [CrossRef]

136. Ding, K.; Lei, J.; Chan, F.T.; Hui, J.; Zhang, F.; Wang, Y. Hidden Markov model-based autonomous manufacturing task orchestration in smart shop floors. Robot. Comput. Manuf. 2020, 61, 101845. [CrossRef]

137. Pujo, P.; Ounnar, F.; Power, D.; Khader, S. Wireless Holon Network for job shop isoarchic control. Comput. Ind. 2016, 83, 12-27. [CrossRef]

138. Lin, C.-C.; Yang, J.-W. Cost-Efficient Deployment of Fog Computing Systems at Logistics Centers in Industry 4.0. IEEE Trans. Ind. Inform. 2018, 14, 4603-4611. [CrossRef]

139. Zulkifli, C.Z.; Semunab, S.N.; Ibrahim, A.B.; Noor, N.M. Implementation of Wireless Mobile Rfid Reader in Real World Industry Environment. J. Teknol. 2016, 78, 74-82. [CrossRef]

140. Leusin, M.E.; Kück, M.; Frazzon, E.M.; Maldonado, M.U.; Freitag, M. Potential of a Multi-Agent System Approach for Production Control in Smart Factories. IFAC-PapersOnLine 2018, 51, 1459-1464. [CrossRef]

141. Cui, Y.; Kara, S.; Chan, K.C. Manufacturing big data ecosystem: A systematic literature review. Robot. Comput. Manuf. 2020, 62, 101861. [CrossRef]

142. Turner, C.J.; Hutabarat, W.; Oyekan, J.; Tiwari, A. Discrete Event Simulation and Virtual Reality Use in Industry: New Opportunities and Future Trends. IEEE Trans. Human-Machine Syst. 2016, 46, 882-894. [CrossRef]

143. Ren, S.; Zhang, Y.; Liu, Y.; Sakao, T.; Huisingh, D.; Almeida, C.M.V.B. A comprehensive review of big data analytics throughout product lifecycle to support sustainable smart manufacturing: A framework, challenges and future research directions. J. Clean. Prod. 2019, 210, 1343-1365. [CrossRef] 
144. Hwang, G.; Lee, J.; Park, J.; Chang, T.-W. Developing performance measurement system for Internet of Things and smart factory environment. Int. J. Prod. Res. 2017, 55, 2590-2602. [CrossRef]

145. Hwang, S. A network clock model for time awareness in the Internet of things and artificial intelligence applications. J. Supercomput. 2019, 75, 4309-4328. [CrossRef]

146. Yu, Q. Design of Logistics Tracking and Monitoring System Based on Internet of Things. J. Residuals Sci. Technol. 2016, 13, 43.1-43.4.

147. Yi, Y.; Yan, Y.; Liu, X.; Ni, Z.; Feng, J.; Liu, J. Digital twin-based smart assembly process design and application framework for complex products and its case study. J. Manuf. Syst. 2021, 58, 94-107. [CrossRef]

148. Kamagaew, A.; Stenzel, J.; Nettstrater, A.; Hompel, M.T. Concept of Cellular Transport Systems in facility logistics. In Proceedings of the The 5th International Conference on Automation, Robotics and Applications, Wellington, New Zealand, 6-8 December 2011; pp. 40-45.

149. Gilchrist, A. Industry 4.0, 1st ed.; O’Reilly Safari Learning Platform: Academic Edition; Apress: New York, NY, USA, 2016.

150. Cheng, Y.; Zhang, Y.; Ji, P.; Xu, W.; Zhou, Z.; Tao, F. Cyber-physical integration for moving digital factories forward towards smart manufacturing: A survey. Int. J. Adv. Manuf. Technol. 2018, 97, 1209-1221. [CrossRef]

151. Kim, J.; Tang, K.; Kumara, S.; Yee, S.T.; Tew, J. Value analysis of location-enabled radio-frequency identification information on delivery chain performance. Int. J. Prod. Econ. 2008, 112, 403-415. [CrossRef]

152. Yang, M.; Mahmood, M.; Zhou, X.; Shafaq, S.; Zahid, L. Design and Implementation of Cloud Platform for Intelligent Logistics in the Trend of Intellectualization. China Commun. 2017, 14, 180-191. [CrossRef]

153. Trappey, A.J.; Trappey, C.V.; Wu, J.-L.; Wang, J.W. Intelligent compilation of patent summaries using machine learning and natural language processing techniques. Adv. Eng. Inform. 2020, 43, 101027. [CrossRef]

154. Liu, Y.; Tong, K.; Mao, F.; Yang, J. Research on digital production technology for traditional manufacturing enterprises based on industrial Internet of Things in 5G era. Int. J. Adv. Manuf. Technol. 2020, 107, 1101-1114. [CrossRef]

155. Meroni, G.; Baresi, L.; Montali, M.; Plebani, P. Multi-party business process compliance monitoring through IoT-enabled artifacts. Inf. Syst. 2018, 73, 61-78. [CrossRef]

156. Westerkamp, M.; Victor, F.; Küpper, A. Tracing manufacturing processes using blockchain-based token compositions. Digit. Commun. Netw. 2020, 6, 167-176. [CrossRef]

157. Wigger, B.; Meissner, T.; Winkler, M.; Foerste, A.; Jetter, V.; Buchholz, A.; Zimmermann, A. Label-/tag-free traceability of electronic PCB in SMD assembly based on individual inherent surface patterns. Int. J. Adv. Manuf. Technol. 2018, 98, 3081-3090. [CrossRef]

158. Wigger, B.; Koinzer, I.; Meissner, T.; Barth, M.; Zimmermann, A. Robust and fast part traceability in a production chain exploiting inherent, individual surface patterns. Robot. Comput. Manuf. 2020, 63, 101925. [CrossRef]

159. Rajagopalan, A.K.; Shyamala, C. A lightweight inter-zonal authentication protocol for moving objects in low powered RF systems. J. Intell. Fuzzy Syst. 2019, 36, 2345-2354. [CrossRef]

160. Tu, M.; Lim, M.K.; Yang, M.F. IoT-based production logistics and supply chain system-Part 1 modeling IoT-based manufacturing IoT supply chain. Ind. Manag. Data Syst. 2018, 118, 65-95. [CrossRef]

161. Li, S.; Da Xu, L.; Zhao, S. The internet of things: A survey. Inf. Syst. Front. 2015, 17, 243-259. [CrossRef]

162. Cannizzaro, D.; Zafiri, M.; Pagliari, D.J.; Patti, E.; Macii, E.; Poncino, M.; Acquaviva, A. A Comparison Analysis of BLE-Based Algorithms for Localization in Industrial Environments. Electronics 2019, 9, 44. [CrossRef]

163. Cheffena, M. Industrial wireless communications over the millimeter wave spectrum: Opportunities and challenges. IEEE Commun. Mag. 2016, 54, 66-72. [CrossRef]

164. Lu, Y.; Liu, C.; Wang, K.I.-K.; Huang, H.; Xu, X. Digital Twin-driven smart manufacturing: Connotation, reference model, applications and research issues. Robot. Comput. Manuf. 2020, 61, 101837. [CrossRef]

165. Kurniadi, K.A.; Ryu, K. Development of IOT-based Reconfigurable Manufacturing System to solve Reconfiguration Planning Problem. Procedia Manuf. 2017, 11, 965-972. [CrossRef]

166. Lai, J.; Luo, C.; Wu, J.; Li, J.; Wang, J.; Chen, J.; Feng, G.; Song, H. TagSort: Accurate Relative Localization Exploring RFID Phase Spectrum Matching for Internet of Things. IEEE Internet Things J. 2020, 7, 389-399. [CrossRef]

167. Gurtu, A.; Johny, J. Potential of blockchain technology in supply chain management: A literature review. Int. J. Phys. Distrib. Logist. Manag. 2019, 49, 881-900. [CrossRef]

168. Krishnamurthy, R.; Cecil, J. A next-generation IoT-based collaborative framework for electronics assembly. Int. J. Adv. Manuf. Technol. 2018, 96, 39-52. [CrossRef]

169. Tao, F.; Cheng, J.; Qi, Q. IIHub: An Industrial Internet-of-Things Hub toward Smart Manufacturing Based on Cyber-Physical System. IEEE Trans. Ind. Inform. 2018, 14, 2271-2280. [CrossRef]

170. La Scalia, G.; Settanni, L.; Micale, R.; Enea, M. Predictive shelf life model based on RF technology for improving the management of food supply chain: A case study. Int. J. RF Technol. Res. Appl. 2016, 7, 31-42. [CrossRef]

171. Crnjac, M.; Veža, I.; Banduka, N. From concept to the introduction of industry 4.0. Int. J. Ind. Eng. Manag. 2017, 8, 21-30.

172. Goudos, S.K.; Dallas, P.I.; Chatziefthymiou, S.; Kyriazakos, S.A. A Survey of IoT Key Enabling and Future Technologies: 5G, Mobile IoT, Sematic Web and Applications. Wirel. Pers. Commun. 2017, 97, 1645-1675. [CrossRef]

173. De Felice, F.; Petrillo, A.; Zomparelli, F. Prospective design of smart manufacturing: An Italian pilot case study. Manuf. Lett. 2018, 15, 81-85. [CrossRef] 
174. Georgakopoulos, D.; Jayaraman, P.P. Internet of things: From internet scale sensing to smart services. Comput. 2016, 98, 1041-1058. [CrossRef]

175. Diez-Olivan, A.; Del Ser, J.; Galar, D.; Sierra, B. Data fusion and machine learning for industrial prognosis: Trends and perspectives towards Industry 4.0. Inf. Fusion 2019, 50, 92-111. [CrossRef]

176. Qiu, T.; Chen, N.; Li, K.; Atiquzzaman, M.; Zhao, W. How Can Heterogeneous Internet of Things Build Our Future: A Survey. IEEE Commun. Surv. Tutorials 2018, 20, 2011-2027. [CrossRef]

177. Kousi, N.; Koukas, S.; Michalos, G.; Makris, S. Scheduling of smart intra-Factory material supply operations using mobile robots. Int. J. Prod. Res. 2018, 57, 801-814. [CrossRef]

178. Cheng, Y.; Chen, K.; Sun, H.; Zhang, Y.; Tao, F. Data and knowledge mining with big data towards smart production. J. Ind. Inf. Integr. 2018, 9, 1-13. [CrossRef]

179. Jeble, S.; Dubey, R.; Childe, S.J.; Papadopoulos, T.; Roubaud, D.; Prakash, A. Impact of big data and predictive analytics capability on supply chain sustainability. Int. J. Logist. Manag. 2018, 29, 513-538. [CrossRef] 